\title{
İktisat Fizik Etkileşimi Bağlamında Ekonofizik ve Gelir Dağıımı
}

Mehmet ÖZYIĞİT (https://orcid.org/0000-0002-6362-9928), Department of Economics, Dokuz Eylül University, Turkey; e-mail:mehmet.ozyigit@deu.edu.tr

İsmail MAZGiT (https://orcid.org/0000-0001-7991-1381), Department of Economics, Dokuz Eylül University, Turkey; e-mail: ismail.mazgit@deu.edu.tr

\section{Econophysics and Income Distribution in the context of Economics and Physics Interaction}

\begin{abstract}
Suppose the $18^{\text {th }}$ century is considered when the modern foundations of classical political economics were laid, and institutionalization of economics has occurred. In that case, it can be said that classical physics especially had essential effects on economics, the $18^{\text {th }}$ and $19^{\text {th }}$ centuries. This historical interaction between economics and the physical sciences is realized through the conceptual and mathematical developments of physics and the economics of defining, predicting, and explaining natural phenomena. In this context, as an interdisciplinary field emerged in recent years, economics is based on the use of laws, theories, and methods developed by the physicists such as uncertainty, stochastic (probabilistic) processes, and economical solutions problems with nonlinear/nonlinear dynamics. The study aims to explain the methods and partnerships of the econophysics studies primarily related to income distribution. Thus, it is attempted to fill the gap in this field in Turkish literature.
\end{abstract}

Keywords $\quad: \quad$ Interaction of Economics and Physics, Econophysics, Income Distribution.

JEL Classification Codes : $\quad$ B19, C46, D31.

\section{$\ddot{\mathbf{O z}}$}

18. yüzyıl Klasik ekonomi politiğin modern temellerinin atıldığ olarak kabul edilirse, özellikle 18. ve 19. yüzyıl klasik fiziğinin iktisat üzerinde önemli etkilere sahip olduğu söylenebilir. İktisat ile Fizik bilimleri arasındaki bu tarihsel etkileşim, fizik biliminin kavramsal ve matematiksel gelişmelerinden ve doğal fenomenleri tanımlama, tahminleme ve açıklama biçimlerinin iktisat tarafından içerilmesiyle gerçekleşmektedir. $\mathrm{Bu}$ bağlamda son yıllarda disiplinlerarası bir alan olarak ekonofizik, fizikçiler tarafından geliştirilmiş olan yasa, teori ve metotları, belirsizlik, stokastik (olasılıksal) süreçler ve doğrusal olmayan/sapmalı (nonlineer) dinamiklere sahip iktisadi sorunların incelenmesi/açıklanması amacıyla kullanılmasına dayanmaktadır. Çalışmanın amacı özellikle gelir dağılımıyla ilgili ekonofizik çalışmalarının yöntemleri ve ortaklıklarının açıklanmasıdır. Böylece Türkçe literatürdeki bu alana dair eksiklik doldurulmaya çalışılmaktadır.

Anahtar Sözcükler : İktisat ve Fizik Etkileşimi, Ekonofizik, Gelir Dağılımı. 


\section{Giriş}

Klasik ekonomi politiğin, toplumların üretim, bölüşüm ve değişim ilişkilerini inceleyen modern bir bilim olarak ortaya çıkışı metanın kullanım değerinin (somut emek) belirli bir amaç için üretici eyleme ve değişim değerinin (soyut emek) eşit toplumsal emeğin ifadesi olarak emek zamanına indirgenmesiyle İngiltere'de William Petty ve Fransa'da Boisquillebert' in eleştirel çalışmalarıyla başlar (Marx, 2005: 51-2). Klasik ekonomi politik olarak iktisadın temellerinin atılması A. Smith'in (1776), Milletlerin Zenginliği çalışmasıyla gerçekleșmiştir. D. Ricardo'nun (1817) çalışmasıyla kurumsallaşarak doruğuna ulaşan ekonomi politik; J.S. Mill (1848) veya Fransa'da J.C. Sismondi ile sona ermektedir ${ }^{1}$ (Kazgan, 2008: vii; Akyüz, 1980: 3; Goodacre, 2015: 91). 1870'li y1llar dönemin üç önemli temsilcisinin Jevons (1871), Menger (1871) ve Walras'in (1874 ve 1898) eserleriyle ${ }^{2}$ klasik değer teorisinde köklü bir değişimin gerçekleşmesi ve iktisat biliminde marjinal fayda kavramının çıkışıyla karakterize olmaktadır. Marjinal fayda kavramının yirmi yıllık bir gecikmeyle de olsa ekonomik analizin merkezine yerleşmesi ve özgün matematiksel yapısı analitik olarak klasik dönemden farklı bir analiz dönemini başlatmıştır (Ertuğrul, 2014: 397 8; Kazgan, 2010: 112-7). Marjinalist teorinin gelişimi A. Marshall, A.C. Pigou, F.Y. Edgeworth ve dönemin diğer iktisatçılarının çalışmalarıyla olgunlaşmıştır. Böylece öncesinin politik ekonomisinin, matematiksel ölçüm ve modelleme yöntemlerinin gelişimiyle formel bir "bilim” olarak iktisada dönüştüğü ileri sürülmektedir. 1945'in ardından Istihdam, Faiz ve Paranın Genel Teorisi eseriyle Keynesyen iktisat, dünya sahnesindeki yerini almış ve iktisat politikalarına egemen olmuştur. 1980'li yıllarda neoklasik iktisadın monetarist yorumu ana akım teori içindeki ağırlığını artırmıştır. Ancak Eren'in (2018: 59; 2011: 19-21) belirttiği üzere 1980 sonrasında iktisadın diğer bilimlerle olan etkileşimindeki artış tek bir ana akım iktisadın varlığından bahsetmeyi güçleştirmektedir. Özellikle 1950'li yıllarda Walrasyan temelli soyut matematiksel iktisat P. Samuelson'un katkılarıyla Walrasyan genel denge ve aynı zamanda Marshall'ın kısmi denge iktisadına karşı ana akıma yerleşmiştir. Diğer taraftan 1980 sonrasında disiplinler arası etkileşimin yol açtığı heterojen ajanlar, doğrusal olmama, rastlantısallık, olasılık (stokastisite), entropi, termo iktisat, kompleksite iktisadı gibi yeni alanların ortaya çıkışı ana akımın yeni klasik iktisadı, reel konjonktür teorilerini ve Keynesyen iktisadı kapsayacak biçimde post-Walrascı iktisat tarafından geniş ölçüde kapsanmasıyla sonuçlanmaktadır.

İktisadın sürekli ve/veya sıçramalı paradigma değişimleri ile gerçekleşen bu tarihsel gelişimi, toplumsal üretim biçimindeki dönüşümler, kapitalist üretim biçiminin tarihsel krizleri ile kendini yeni toplumsal koşullara uyumlaması ve iktisadın diğer bilimlerle, özellikle fizik bilimiyle olan etkileşimi sonucunda ortaya çıkmaktadır. Sosyal bilimler ile doğa bilimlerinin yöntemleri arasında farklılıklar söz konusuysa da iktisat ve fizik etkileşimi üretken bir alan olarak varlığını sürdürmektedir.

1 Adam Smith (1776) "Milletlerin Zenginliğinin Mahiyeti ve Nedenleri Üzerine Bir Araştırma"; David Ricardo (1817) "Siyasal İktisadin ve Vergilendirmenin Temel İlkeleri" John Stuart Mill (1848) "Politik Ekonominin İlkeleri".

2 William Stanley Jevons (1871) "Politik Iktisadın Teorisi”; Carl Menger (1871) “iktisat Illkeleri” Leon Walras (1874 ve 1898) "Salt Politik İktisadın Unsurları" ve "Uygulamalı Politik İktisat Çalışmaları". 
Özyiğit, M. \& İ. Mazgit (2021), "İktisat Fizik Etkileşimi Bağlamında

Ekonofizik ve Gelir Dağılımı”, Sosyoekonomi, 29(48), 377-405.

$\mathrm{Bu}$ bağlamda çalışma üç kısımdan oluşmaktadır. Birinci kısımda iktisadın fizik bilimiyle olan tarihsel etkileşimi incelenecektir. İktisat ve fizik arasındaki tarihsel etkileşim, fiziğin genel olarak bilimselliği ve pozitif bilimler içindeki konumu, pozitivizmin etkisiyle deney ve gözlemin bilimsellik üzerindeki etkisi nedeniyle iktisatçıların matematik kullanımına yönelmelerine ve iktisadın "bilimselleşme" sürecinde pozitif bilimlerle kurduğu ilişkilerin artmasına neden olmuştur. İktisat veya sosyal bilimler doğa bilimlerinden farklı olarak insan davranışları, bireyler arasındaki toplumsal ilişkiler ve bu bireyler arasındaki ilişkilerin ortaya çıkardığı kurumların incelenmesiyle ilgiliyse de (Kazgan, 2010: 31), Newton fiziği ve Öklid geometrisi ile klasik iktisadın, termodinamik ${ }^{3}$ ve diferansiyel denklemler ile neoklasik iktisadın; Einstein fiziği ve Riemann geometrisi ile Keynesyen teorinin ve kuantum fiziği ve topoloji ile genel denge iktisadının ilişkisi, iktisat ile fizik arasındaki tarihsel etkileşimin kavranması açısından önemli olduğu iddia edilmektedir (Eren \& Öğüt, 2009; Mirowski, 1995). Bu etkileşim, diyalektik iktisadi ilişkilerin matematiksel olarak kurgulanması, modellenmesi ve niceliksel olarak açıklanmasına daha fazla olanak sağlaması açısından da önemlidir. Çalışmanın ikinci kısmı 1990'ların ortasında, fiziğin bir alt dalı olan istatistiksel fizik alanında çalışan bir dizi fizikçinin, ekonominin ve özellikle finansal piyasaların neden olduğu karmaşık problemleri kavrama ve açıklamaya karar vermesiyle başladığı söylenebilecek ekonofizik kavramının ve bu kavramın tarihsel gelişiminin açıklanmasını kapsamaktadır. Fizikteki özellikle istatistiksel fizikten yararlanılarak olasılıksal ve istatistiksel kuram ve yöntemlerin kullanılmasıyla ekonomik problemlerin açıklanmasını/incelenmesini amaçlayan ve disiplinlerarası bir alan olarak tanımlanan ekonofiziğin iktisadın son dönem tarihsel gelişimindeki yeri kavranmaya çalışılmaktadır. Çalışmanın üçüncü kısmı ekonofizik yöntemin gelir ve servet dağılımının analizinde kullanımını açıklamaya odaklanmaktadır. Ekonofizik, ortaya çıkış koşulları ve temel ilgi alanı olarak başlangıçta daha çok yüksek varyanslı finansal zaman serilerinin ve borsa verilerinin analizine odaklanmışsa da zaman içinde gelir ve servet dağılımıyla ilgili ekonofizik yöntemlerin kullanıldığı bir uluslararası literatürden bahsetmek de mümkündür.

3 Termodinamik, Yunanca therma (isl) ve dynamis (güç) kelimelerinin bileşiminden meydana gelen enerjinin bilimi olarak tanımlanabilir. Enerji kesin olarak tanımlanmamakla birlikte genel olarak, iş yapabilme yetisi veya bir değişikliğe yol açan etken olarak tanımlanmaktadır. Termodinamiğin dört temel yasası bulunmaktadır. 0. Yasa: eğer iki sistem birbiriyle etkileşim içindeyken aralarında usı veya madde alışverişi olmuyorsa bu sistemlerin termodinamik dengede olduğunu belirtir. Illk olarak 1931 yllinda Fowler, R.H. tarafindan, 1. ve 2. Yasadan yaklaşık yarım yüzyıl sonra ortaya atılmış, temel bir bilgidir ve bu nedenle sifirincı yasa olarak adlandirlmaktadır.

1. Yasa: Bir sistemin iç enerjisindeki değişim, sisteme verilen isı ile sisteme çevre tarafindan uygulanan iş toplamıdır. $U_{2}-U_{1}=Q+W$ ile ifade edilebilecek bu yasa aynı zamanda "Enerjinin Korunumu" olarak bilinmektedir. Diğer bir ifadeyle enerji yoktan var edilemez, var olan enerji de yok edilemez; sadece bir şekilden diğerine dönüşür. Enerji, cins değiştirmektedir.

2. Yasa: Hiçbir enerji, kayba uğramadan cins değiştiremez. Yani, enerji bir durumdan diğeri bir duruma geçerken bir miktar enerji kaybolmaktadır. Diğer bir ifadeyle "Bir ısı kaynağından ısı çekip buna eşit miktarda iş yapan ve başka hiçbir sonucu olmayan bir döngü elde etmek imkânsızdır". (Kelvin-Planck Bildirisi) veya "Soğuk bir cisimden sıcak bir cisme usı akışı dışında bir etkisi olmayan bir işlem elde etmek imkânsızdır". (Clausius Bildirisi) Buna "entropi" denmektedir. Yani termal olarak izole edilmiş büyük bir sistemin entropisi hiçbir zaman azalmaz. Dolaylsılyla düzensizlik ya değişmez ya da artar.

3. Yasa: bir maddeyi mutlak sıfira kadar soğutmanın imkânsız olduğunu belirtir. Sicaklık mutlak sıfira yaklaştıkça bütün hareketler sıfira yaklaşır. Dolayısıyla mutlak enerjisiz bir ortam elde etmek mümkün değildir. En soğuk ortamda bile bir sicakllk söz konusudur/vardır. 
Bu bağlamda üçüncü kısım bu uluslararası literatürün tanıtılmasını amaçlamaktadır. Çalışma ortaya konulan kavramsal yapı ve yöntem bağlamında ekonofiziğin özellikle farklı gelir ve servet dağılımı çalışmalarına olanak tanıyıp tanımadığını tartışan sonuç kısmıyla tamamlanmaktadir.

\section{2. İktisat ve Fizik Etkileşimi}

Çalışmanın bu kısmında iktisat fizik etkileşiminin tarihsel arka planından söz edilecektir. Bu bağlamda bölüm "son tahlilde" diye başlayan keskin bir yargı geliştirmek yerine, iktisat fizik etkileşiminin son dönemdeki disiplinler arası çalışmaların bir sonucu olan ekonofiziğin, iktisada katkı sağlayabilecek bir alan olarak değerlendirilmesinin tarihsel temellerine değinmeyi amaçlamaktadır.

Fiziğin sosyal bilimlerle olan ilişkisi, Kopernik'in enflasyon davranışlarını incelediği, sonrasında Greshnam Kanunu olarak bilinecek olan yasanın teorik temellerini kurduğu 1526 yılına kadar götürülebilir (Bentes, 2010: 2; Yakovenko, 2008: 1). Fizik biliminin tarihsel gelişiminde iki temel köşe taşından bahsedilebilir. Bunlardan ilki 17. yy. Bilim Devrimi olarak adlandırılan; Galileo, Descartes ve Newton tarafindan temelleri kurulan klasik fizik, diğeri ise kuantum mekaniği ve görelilik (relativity) temelindeki 20. yüzyıl fiziğidir (Kırer, 2011: 5; Mirowski, 1984: 365). Özellikle Newton (1643-1727) tarafından külte çekim yasasının (evrensel çekim yasası) açıklanmasıyla yalnızca genel olarak bütün bilimlerde evrenin anlaşılmasında rasyonalizme, deneyselliğe, determinizme ve tümevarıma dayanan bir yöntem ortaya çıkmıștır (Pereira, vd., 2017: 252). Newton'un hareketin yasalarını ortaya koymasıyla ölçülebilir değişkenler arasındaki deterministik ilişkilerin kurulması, dünyaya ilişkin parametrelerin gözlemler aracılığı ile klasik fizik tarafından hesaplanabileceği düşüncesi döneme damgasını vurmuştur. Descartes’in üçboyutlu, zamansız ve tersinir evreninin mekanik süreçleri açıklanmıştır. Böylece klasik mekanik ekonominin bir modeli olmasa da ekonomik bir model olarak değerlendirilebilir (Sebba, 1953: 260-1). Progogine ve Stangers (1998), Newton mekaniğinin yaygınlaşmasıyla evrenin yalnızca mekanik terimlerle tanımlandığını ifade etmektedir. Newton sonrası dönem, yöntemsel olarak, doğada rastgeleliğe yer bırakmamaktadır. Bu dönemin temel çabasının evreni anlamaktan çok, evrene hâkim olmak olduğu ve evren hakkındaki bilinmezliklerin ve belirsizliğin bilgi eksikliğinden kaynaklandığı ifade edilmektedir. Böylece bütün, parçaların toplamı olarak ele alınmakta ve kompleks bir yapının parçalara ayrılarak basit alt sistemler yardımıyla açıklanabileceği belirtilmektedir. 1900 yılında Max Planck'1n kuantum teorisi ve 1905 yılında Albert Einstein'ın görelilik kuramı ile fizik bilimi bir devrim yaşamıştır. Fizikteki bu değişim R. Hollinsworth ve K.H. Mülller (2008: 400) tarafından aşağıdaki tablo ile özetlenmiştir. Tabloda bilim I olarak anılan, değişim öncesi hal iken bilim II ile değişimden sonraki hal anlatılmaktadır. 
Tablo: 1

Bilim I ve Bilim II Arasındaki Farklar

\begin{tabular}{|l|l|l|}
\hline & Bilim I & Bilim II \\
\hline Bilimin Başlıca Alanları & Klasik Fizik & Evrimsel Biyoloji ve Karmaşıklık/Kompleksite Bilimi \\
\hline Teorik Amaç & Genel, evrensel kurallar & Örnek (pattern) biçimlendirme ve tanımlama \\
\hline Teorik Perspektif & Aksiyomatik, İndirgemeci & $\begin{array}{l}\text { Olgu, gerçeğin çitli düzeylerinde eşzamanlı olarak içiçe } \\
\text { girmiş durumda }\end{array}$ \\
\hline $\begin{array}{l}\text { Tahminleme kapasiteleri veya öngörü } \\
\text { yapabilme yeteneği }\end{array}$ & Yüksek & Düşük \\
\hline Karmaşıklık & Düşük & Yüksek \\
\hline Ontoloji & Düalizm & Monoizm, çok karmaşık mimari ile birlikte \\
\hline Değişimdeki Perspektif & $\begin{array}{l}\text { Durağanlığı, denge durumundaki doğrusal } \\
\text { olguyu vurgulamakta }\end{array}$ & $\begin{array}{l}\text { Dinamizm, açık sistemler, dengeden uzak işlemi } \\
\text { vurgulamakta }\end{array}$ \\
\hline Dağılım Olgusu & $\begin{array}{l}\text { Normal dağılım üzerinde durmakta, } \\
\text { dağılım çan eğrisi biçiminde }\end{array}$ & $\begin{array}{l}\text { Kit ve uç noktalardaki olayların üzerinde durmakta, güç } \\
\text { yasasına uyumlu olgulara duyarlı }\end{array}$ \\
\hline Mikro-Makro Ayrımları & $\begin{array}{l}\text { Mikro ve makro düzey süreçler ayrık ve } \\
\text { farklı görülür }\end{array}$ & $\begin{array}{l}\text { Makro olgular, ortak mikro düzey davranışlardan meydana } \\
\text { gelmektedir }\end{array}$ \\
\hline Disiplinler arası araştırma potansiyeli & Düşük & Yüksek \\
\hline Başlıca Metaforlar & Saatler & Karmaşı ağlar, canlı hücreler, bulutlar \\
\hline $\begin{array}{l}\text { Sosyal ve Doğa Bilimleri Arasındaki } \\
\text { Bilişsel Uzaklıklar }\end{array}$ & Yüksek & Orta \\
\hline İlham veren bilimciler & R. Descartes, I. Newton, A. Smith & C. Darwin, I. Prigogine, G. Edelman \\
\hline
\end{tabular}

Kaynak: Hollingworth \& Müller (2008: 400).

İktisadın temel özelliklerinden biri de diğer doğa bilimleriyle etkileşimi aracılığıyla zenginleşmesidir. 18. yüzyıl iktisat biliminin modern temellerinin atıldığ 1 ve kurumsallaştığ 1 yüzyıl olarak kabul edilirse, özellikle 18. ve 19. yüzyıl klasik fiziğinin iktisat üzerinde önemli etkilere sahip olduğu söylenebilir. Ayrıca klasik iktisat, neoklasik teori ve iktisadın 21. yüzyıldaki güncel teorileri fizik biliminin kavramsal ve matematiksel gelişmelerinden ve doğal fenomenleri tanımlama, tahminleme ve açıklama biçimlerinden etkilenmişlerdir (Daniel \& Sornette, 2008: 1). Kırer (2011: 6-7) 18. ve 19. yüzy1l klasik fiziğinin, iktisat üzerinde önemli etkisi olduğunu ifade eder. Klasik iktisadın kurucusu olan Smith dahil klasik iktisatçıların Öklid geometrisi ve Newton fiziği temelinde, gerçeğin idealize edildiği modellerin inşa ve manipülasyonu sonucu elde edilen bilginin tümden-gelimci sistematikleştirilmesiyle, disiplinlerini fizik yöntemlerine göre yeniden modellemeye çalışmışlardır.

Klasik iktisadın ortaya çıkışından bugüne, literatürde fizikçilerin iktisadi ve finansal sorunlara olan ilgisini ve bu sorunlarla etkileşimini gösteren örnekler söz konusudur. Daniel Bernoulli (1738) insanların tercihlerini tanımlamak için fayda düşüncesini ortaya atmışıtır. Pierre-Simon Laplace (1812), ekonomide rastlantısal veya öngörülemeyecek gibi görünen olayların, oldukça öngörülebilir ve temel yasalara olan uyumluluklarının gösterilebilir olduğu fikrini ileri sürmüştür. Adolphe Quetelet (1835) ilgi alanını, Laplace'ın düşüncelerini veri setlerindeki kalıpların varlı̆gına uygulayarak ekonomik sorunlardan sosyal problemlere genişletmiştir. Ayrıca fiziksel yasaların insan davranışlarını ve ekonomiyi yönlendirebileceği düşüncesini kuvvetlendirmiştir. Aynı zamanda çağdaşı Aguste Comte (1798-1857), "sosyal fiziği” bilimsel bir alan olarak ilk tasarlayan kişidir. Ekonomik olguları bireylerin istatistiksel davranışları açısından anlamak üzere ilk girişimler, J.C. Maxwell (1831-79) ve L. Boltzman (1844-1906) tarafından temelleri oluşturulan istatistiksel mekanikten etkilenmiştir. Böylece A. Marshall (1842-1924) ve F. Edgeworth (1845-1926) gibi pek çok iktisatçı, iktisadi sistemlerin fiziksel sistemler gibi bir dengeye ulaşabileceği kavramını bu fizikçilerin çalışmalarından hareketle detaylandırmışlardır. 1871 yılında W.S. 
Jevons, iktisadın gelişimini fayda ve kişisel çıkarın mekaniğine benzer biçimde planlamıştır. Walras, kıtlık kavramının matematikselleştirilmesi için çalışmış ve diğer koşullar veri iken fiyatların talep edilen miktar ile ters ve arz edilen miktar ile doğru orantılı olduğunu varsayarak piyasa ilişkilerinin Newtongil bir modelini uygulamaya çalışmıştır (Kırer, 2011: 8-9). Irving Fisher, neoklasik iktisadın ortaya çıkışında önemli bir role sahiptir. 18. yüzyıl sonlarında ve 19. yüzyılda J.L. Lagrange, W.R. Hamilton ve diğerleri, Newton'un teorilerini analitik mekanizmanın daha modern teorilerine çevirmişlerdir. Bu durum iktisatçıları da etkileyerek, iktisadın matematiksel olarak şekillenmesinde kullanılmıştır (Burda vd., 2003: 2). Luis Bachelier (1900), doktora tezinde "rassal yürüyüşün" (matematiksel etkin piyasalar modeli) formülasyonunu gerçekleştirmiştir. Çalışması spekülatif piyasalarda opsiyon fiyatlaması için bir ilk niteliğindedir ve finansal piyasalar için oldukça önemlidir. Aynı zamanda iktisadi veri tabanında Brownian Hareketi teorisini geliştirmiştir. Bachelier’in ardından A. Einstein, rastgele yürüyüşü matematiksel olarak formülleştirmiştir. Ettore Majorana (1938) öngörülü bir biçimde istatistiksel fiziğin yöntemlerinin sosyoekonomik olgulara uygulanmasının olanaklarına ve tehlikelerine dikkat çekmiştir. Nobel Ödüllü (1969), ekonometrinin ve makroekonominin kurucuları arasında olmasının yanında gelir dağılımı ve optimal toplumsal işleyişle ilgili çalışmalar gerçekleştirmiş olan Jan Tinbergen yine bir fizikçidir. Leon Walras ve Vilfredo Pareto'nun ekonomik denge üzerine yaklaşımları mekanik dengenin fiziksel temellerine dayanmaktadır. Pareto, 1897'de yazdığı Cours d'économie Politique (Politik İktisat Dersleri) ile gelir ve refah dağılımıyla ilgili olarak GSYİH veya bir ülkedeki şirketlerin büyüklükleri gibi değişkenlerle gerçekleştirdiği çalışmalarla daha sonra doğal veya toplumsal olayların büyüklüklerinin dağılımını açıklamada merkezi bir öneme sahip olacak güç yasaları (Power Laws) kavramını ilk tanımlayan düşünürdür. Pareto, farklı ülkeler ve şehirler arasındaki refah dağılımının Pareto Endeksi olarak bilinen benzer bir $\alpha$ kuvvetiyle güç yasası dağılımı gösterdiğini ileri sürmüştür (Daniel \& Sornette, 2008: 2; Coelho, 2007: 5; Pereira, 2017: 252). Gausyen dünyadaki bir diğer dönüşüm bilgisayar tekniklerinin gelişimiyle ortaya çıkmıştır. Bilgisayarların, hızı, işlem genişliğini ve veri toplanmasındaki exponansiyel artışı önemli biçimde artırması ekonomilerin ve piyasaların birbirlerini daha yakından izlemesini olanaklı kılmıştır. Böylece sapmalara neden olan pek çok çözümü zor birliktelikler ekonomilerde görünür hale gelmeye başlamıştır. İktisatçıların geleneksel açıklamaları yerine fiziğin yöntem ve araçlarını öncelikle finansal verilere sonrasında ise daha genel ekonomik sorunlara uygulamışlardır. 1950'li yıllarda A. Alchain, 1971'de N. Georgescu-Roegen ve 1981 'de K. Boulding' in iktisada evrimsel bakış açısıyla yaklaşımları ve 1982 yılında Nelson ve Winter'in çalışmaları izleyen dönemde iktisat içinde evrim kavramını yeniden öne çıkarmıştır. 1984 yılında Santa Fe Enstitüsü'nün kurulması ve karmaşıklık iktisadının ortaya çıkışı, Ajan-Bazlı Hesaplamalı İktisat çalışmalarının bilgisayar teknolojileri ile birleşmesi bu iki ayrıksı bilim arasındaki boşluğun kapanmasına neden olmuştur (Kırer \& Ercan, 2015: 28). Yakovenko (2008), iktisat ve fizik ilişkisinde Pareto'nun çalışmasının yüksek ve düşük gelir dağılımlarının ilişkisinde güç yasasının geçerli olduğunu vurgulamasıyla bir dönüm noktası oluşturduğunu belirtmektedir. Spekülatif fiyat teorisindeki en devrimci dönüşümlerden biri Mandelbrot'un, fiyat değişimlerinin Gausyen dağılım yerine durağan Levy dağılımını izlediği hipotezidir. Poincare (1854-1912), kaotik davranışların temellerini kurarak, o döneme değin finans teorisi içinde kabul gören varlık fiyatlarının zaman 
serilerinin tahmin edilemezliği düşüncesine karşı, tahmin edilemezliğin olasılığına işaret etmiştir. Böylece kaos teorisi, teorik fiziğin ana çalışma alanlarından biri haline gelmiştir (Sharma vd., 2011: 3-4; Carbone, Kaniadakis \& Scarfone, 2007: xi). Tüm bu gelişmeler özellikle 19. yüzyılın ikinci yarısında istatistiksel mekaniğin gelişimine katkı sağlamıştır. J.C. Maxwell, L. Boltzman ve J.W. Gibbs bu sürecin öne çıkan fizikçileridir. Atomların varoluşu ve istatistiksel özelliklerini açıklamak için gelişmiş matematiksel yöntemler kullanmışlardır. Örneğin bir gazın içindeki moleküllerin "vektörel hızlarının dağılım olasılığı" (Maxwell-Boltzman Dağılımı) ile farklı enerjili durumların "genel olasılık dağılımı" (Boltzman-Gibbs Dağılımı) gelişmiş matematiksel yöntemlerin kullanıldığı başlıca çalışmalardır (Kırer, 2011: 10; Yakovenko, 2008). Ancak iktisadın doğa bilimleriyle kurduğu bu karşılıklı etkileşim, 1930'larda, iktisadın sorun alanının da değişimiyle ${ }^{4}$, görünür olmaktan çıkarak farklı biçimde devam etmiştir. 1980'li yıllara değin iktisat ve doğa bilimleri varlıklarını görece ayrıksı biçimde sürdürmüştür. Belirtmek gerekir ki, bu dönem, iktisada içerilmiş temel fizik kavramlarının terk edildiği bir dönem değildir. Aksine iktisada içerilmiş temel fizik kavramlarından biri olan denge gibi temel kavramlar teori içindeki önemini muhafaza etmiştir. Ancak 1980'li yılların sonu, kavramların ortaya konuşunda deterministik ilişkiler yerine olasılıksal ilişkilerin temel alındığı veya ağır bastığı, yeni bir etkileşimle karakterize edilmektedir.

1980’ler ile finansal verilerin büyük ölçekte ulaşılabilir hale gelmesiyle, homojen iktisadi bireyler ve denge yaklaşımına dayalı iktisadi çözümlemeler yerine özellikle finansal piyasalarda kendini gösteren heterojen iktisadi birey ve dengeden uzaklık durumlarını dikkate almaya başlamışlardır. Dalgalanmalar konusunda Gausyen ilkelerin sapmalı davranışları ve aşırı tahminleri 1987 yılında Kara Pazartesi Çöküşünden, 1998 yılındaki Ağustos ve Eylül krizlerinden ve 2007-08 (yüksek faiz artış1) ${ }^{5}$ krizinden sorumludur. Ancak bu şoklar aynı zamanda Poincare'in çok önceden dikkat çektiği, doğrusal olmayan/sapmalı etkilerin önemini, kaotik davranışların temellerinin kurularak sapmalı bir sistemde öngörülemezliğin olasılığı konusunu gündeme getirmiştir. Tüm bu gelişmeler büyük ölçekli ve anlık verilerle uyumlu yeni yöntemlerin ortaya çıkmasını gerektirmiştir. Özellikle düzenlilikler ve geleneksel olmayan ilişkiler arayan yöntemler açısından fizikten geniş ölçüde ödünç alınan bu yöntemler zorunludur (Sharma vd., 2011: 3-4). Nitekim, 1980’lerde karmaşıklık sürecinin iktisat tarafından yeniden hatırlanması, değişme, doğrusal olmama (nonlinearity), kendi kendine organizasyon (self organization), süreksizlik, rassallık (randomness), birbirini etkileme gibi kavramların yeniden iktisat tarafından içerilmesiyle sonuçlanmıştır.

1970'li yıllarda doğa bilimciler, mikroskobik etkileşimlerin makroskobik davranışların kalıplarının ortaya çıkışını belirlediği, "karmaşık uyumcu sistemlerin" (complex adaptive systems) varlığını teorileştirmişlerdir. Geleneksel dinamik sistemler ile

\footnotetext{
1930 'lu yıllarda iktisadın sorun alanının değişimi ifadesiyle kalkınma iktisadının yükselişi belirtilmektedir. Bu dönem yöntemsel açıdan iktisat ile doğa bilimleri etkileşiminin görünmez olmasının nedenlerinden biridir.

5 2007-08 krizi kapitalist üretim ilişkileri açısından bir tarihsel kriz olmakla birlikte, Subprime Mortgage piyasalarındaki krizi tetikleyen olay, Fed'in faiz düşüş döngüsünden faiz artış döngüsüne girmesidir. Bu nedenle yüksek faiz krizi olarak da tanımlanmaktadır.
} 
karmaşık uyumcu sistemler arasındaki göreli farklılık, dinamik davranışların, sistemin içsel yapısı nedeniyle tekil bireylerin mikroskobik hareketlerinin sonucu kendiliğinden ortaya çıkmasıdır. Böylece 20. yüzyılın sonunda iktisatçıların ekonomik olguları modelleme deneyimleri geleneksel teoriler ile önemli ölçüde farklılaşmıştır. Rasyonel birey varsayımı iktisadi insanın Platoncu aşırı basitleştirilmiş idealist bir biçimi olarak algılanmaya başlandığ 1 ifade edilmektedir (Carbone, Kaniadakis \& Scarfone, 2007: xii). Bu koşullarda ekonofizik, disiplinler arası bir araştırma alanı olarak, iktisadi problemlerin çözümünde istatistiksel fizikçiler tarafından geliştirilen teori ve yöntemleri uygulayan bir alan olarak ortaya çıkmaktadır. Bu bağlamda ekonofizik ile uğraşan bilimciler, hisse senedi piyasaları ve sosyoekonomik sistemlerde ortaya çıkan toplam davranışları tanımlamak için ölçeklendirme, evrensellik, faz geçişleri ve sızma gibi kavramları ve modelleri uygulamaktadirlar.

\subsection{Klasik İktisadın Fizik Kökenleri}

Klasik iktisadın bilimleşme sürecinin kökenlerinde Newton fiziği ve Öklid geometrisinin etkisi son derece büyüktür. Kapitalizmin gelişimi, aydınlanma felsefesinin ortaya çıkışını sağlamış ve iktisadın bir bilim olarak kabul edilmesi; insanın evreni anlama çabasının o güne kadarki doruk noktası olan aydınlanma düşüncesi ve bu düşünce içindeki en önemli bilim dallarından biri olan fiziğin etkisiyle gerçekleşmiştir (Afşar, 2013: 141; Birner, 2002: 68). Fizik biliminin Newtongil yasalarının klasik iktisadın temeline yerleşmesiyle, ekonominin genel yasalarının keşfinde doğrudan Newton'un hareketin doğal yasalarını keşif sürecindeki örneklerinden ve çalışmalarından esinlenilmiştir. Newton'un teorisi, yöntemsel olarak Bacon'ın ampirizmi ile Descartes'in tümdengelimci yönteminin bir sentezidir. Sürekli hareket halinde devinen gerçeğin statik bir resminin gerçekle özdeş olduğu varsayımı, matematiği doğa felsefesinin temel aracı haline getirmiştir. Kant'ın deyişiyle, doğa felsefesinde ne kadar matematik varsa o denli gerçek anlamda bilim vardır (Stremlin, 2007: 28-9). Klasik iktisatçılar, matematikselleştirilmeye ve büyük ölçüde tahmin yapmaya elverişli olan genel mekanik modellerle temsil edilen bir modern ekonominin hesaplanabilir özellikleri ile büyük bir keşif gerçekleştirmişlerdir. Gelişmekte olan kapitalist sistem iktisadi süreçleri hızlı bir şekilde rasyonel ve hesaplanabilir biçime dönüştürürken aynı zamanda onlara daha önce sahip olmadıkları bir toplumsal egemenlik de bağışlamıştır (Sebba, 1953: 261-2). A. Smith'in “görünmez el” kavramını ortaya atışı ile Darwin'in (18091882) biyolojik uyum ve doğal seçilim süreçlerinde rekabetin düzenleyici bir gizli güç olduğu hipotezi arasındaki benzerlik dikkat çekicidir. Hetherington'a (1983: 498) göre, A. Smith, ekonominin genel yasalarını keşfinde doğrudan Newton'un hareketin doğal yasalarını keşif sürecindeki örneklerinden ve çalışmalarından esinlenmiştir. A. Smith'in modeli esasen genel bir mekanik denge modelidir. Dolayısıyla bu ilişki aynı zamanda iktisat fizik ilişkisinin temeli olan denge kavramının önemini de ortaya koymaktadır. Smith'in doğal fiyatı, piyasada oluşan diğer fiyat biçimlerini, ücretleri, mal fiyatlarını vd. kendine çeken bir merkez olarak tanımlaması ve bu ilişkiyi evrensel bir yasa üzerinden kurgulaması da Newton'un evrensel kütle çekim yasasının iktisada içerilmesinin örneklerinden biridir. Ayrıca arz ve talep yasalarında Newton'un her etkinin bir tepki yarattığını tanımlayan hareket yasalarından üçüncüsü ile ilgili benzerlikler görülebilmektedir. Bu dönem 
iktisadında, fizikçilerin doğayı açıklamalarındaki mekanik modellemelerine benzer olarak toplumun mekanik modellenmesi temel yöntemlerden biridir (Sonüstün \& Gül: 2012: 37).

Böylece sosyal bilimler, yöntem olarak doğa bilimlerinden analojilerle veya onları taklit ederek bilimselliklerini ispatlamaya çalışmaktadırlar. Klasik politik iktisatçılar, gerçekliğin idealize modellerinin manipülasyonu ve inşasıyla elde edilen bilginin tümdengelime göre sistematikleştirilmesiyle, bilinçli olarak fiziğin yöntemleri üzerinden teorilerini yeniden modellemeye çalışmışlardır. Elde ettikleri "bilimsellik" ile ampirik olarak doğrulanabilir, "değerlerden bağımsız" ve evrensel bilgi üretme yolunda inceledikleri iktisadi ve/veya toplumsal ilişkileri meşrulaştırma ve işlevsel yeterliliklerini sağlayarak bilimler arasında yerlerini alma iddiasında bulunmuşlardır (Mielants, 2007: 66; Afşar, 2013: 142-3).

\subsection{Neoklasik İktisadın Fizik Kökenleri}

"Marjinalist Devrim" olarak da adlandırılan neoklasik iktisat kuramı esas olarak birbirinden bağımsız ancak aynı dönemde, Jevons, Menger ve Walras tarafindan gerçekleştirilen, statik mikroekonominin temel yapı taşı olarak azalan marjinal fayda prensibini esas alan çalışmalarıyla ortaya çıkan iktisadın yeni biçimini tanımlamak amacıyla kullanılmaktadır (Blaug, 1985: 294). Mirowski (1984) iktisadın tarihsel gelişiminde, enerjinin korunumu yasasının iktisat tarafından keşfinin önemli olduğunu belirtmektedir. 19. yüzyılın sonlarında enerji kavramının ortaya çıkışı, fayda kavramıyla kurulan benzerlikle Neoklasik iktisadı biçimlendirmiştir. Enerji bilimine olan ilginin artışı, fizikteki paradigmayla uyumsuz özellikler barındıran termodinamiğin doğmasına neden olmuştur. Newtongil mekanikten 19. yüzyıl fiziğine geçiş ile klasik iktisattan neoklasik (marjinalist) iktisada geçiş arasında güçlü bir bağ söz konusudur (Çakır, 1998; Afşar, 2013: 145; Kırer \& Eren, 2015: 33). Brahmachari (2016: 3) 20. yüzyılın ortalarında pozitivizm ve yanlışlamacılığın iktisadın yöntemi üzerinde derin bir etkide bulunduğunu belirtmektedir. Bu etkiyi 1950'li yıllarda M. Friedman'ın çalışmalarıyla ve pozitif iktisadın, fiziksel bilimlerin herhangi biri gibi açık bir biçimde objektif bir bilim olduğu veya olması gerektiği ifadesiyle temellendirmektedir. Bu bağlamda neoklasik teori, termodinamik ve diferansiyel ile tanımlanmaktadir.

Walras'a göre bilim evrensel karakteristiğe sahip olguları konu edinmelidir. Walras'ın iktisadi kurgusu ele alındığında Kartezyen felsefenin önemli bir yer kapladığı anlaşılmaktadır. Bu bağlamda Koppl'a (1992: 17) göre bu Kartezyen anlayış mekanik bir fiyat teorisinin oluşturulmasına ve teorinin Kartezyen fiziğin bir dalı olarak değerlendirilmesine; bu durumun ise ampirik olarak test edilmesi zor bir denge teorisinin inşasıyla sonuçlanmasına neden olduğu söylenebilir. Ayrıca Kartezyen felsefenin bir uzantısı olarak Walras'ın pozitivist bilim anlayışını benimsediği ifade edilebilir. Afşar'a göre (2013: 145) Walras, mekanik ve iktisat arasındaki ilişkiyi, fayda ve terazi arasında kurguladığı matematiksel bir analojiyle analiz etmektedir. Neoklasik teoride toplumsal ve iktisadi dengenin, eş marjinallik ilkesi ile bireysel dengenin sonucunda ortaya çıktığ varsayılmaktadır. Bu varsayım ve analojiyle tüketici bireylerin dengesi her mala yaptıkları harcamaların son biriminden elde ettikleri malların marjinal faydalarının eşitliğiyle 
sağlanmaktadır. Üretici bireylerin üretim faktörlerine yaptıkları harcamaların son birimlerinden elde ettikleri kazançlar veya fiyatların oranının eşitlenmesi ise üretici dengesini göstermektedir. Dolayısıyla Walras, niceliksel olarak ölçülemeyen psikolojik faktörlerin (fayda vb.), ölçülebilir büyüklükler (fiyat vb.) cinsinden ifade edilmesiyle iktisatta ölçüm sorununun üstesinden gelinebileceğini savunmaktadır.

Neoklasik iktisadın egemen çizgisi termodinamiğin iktisada uyarlanmasıdır. Kıtlık kavramı ve Fisher'1n miktar kuramı, termodinamiğin birinci yasasının iktisada uyarlanmasının başka bir biçimde ifadesidir. Samuelson, iktisatta marjinal kavramını türev, diferansiyel problemine indirgeyerek, maksimizasyon kavramını, optimizasyon problemi olarak görmüştür. Özellikle 1950'li yıllarda Arrow-Debreu ile üst düzeye çıkan matematik kullanımıyla iktisatta dengenin varlığ 1 ve kararlılığ Bunun için sabit nokta kuramından faydalanılmıştır. Ayrıca Nash dengesi de kanıt olarak gösterilmiştir (Eren, 2011: 16). İktisadın Fisher denkleminde (P.T $\equiv$ M.V) paranın dolaşım hızı olarak ifade edilen V, fizikteki hız (velocity) analojisi kullanılarak oluşturulmuştur. Ayrıca Fisher (1925: 85) fizik ile iktisat arasındaki kavram analojilerini aşağıdaki Tablo ile özetlemektedir.

Tablo: 2

Fisher'ın Fizik-İktisat İlişkisi

\begin{tabular}{|l|l|}
\hline Mekanik & Íktisat \\
\hline Parçacık/A Particle & Birey/An Individual \\
\hline Uzay - Mekân/Space & Mal - Meta/Commodity \\
\hline Güç/Force & Marjinal Fayda veya Yararsılık - Istırap/Marginal Utility Of Disutility \\
\hline İş/Work & Istrap/Disutility \\
\hline Enerji/Energy & Fayda/Utility \\
\hline
\end{tabular}

Kaynak: I. Fisher (1925).

Fisher (1925: 85-6) analojilerinde, iş veya enerjinin = kuvvet x uzay’a eşit olduğunu bunun iktisattaki karşılığı olarak fayda = marjinal fayda $\mathrm{x}$ mal eşitliğini kullanır. Fizikteki kuvveti vektörel bir büyüklük olarak tanımlar ve iktisada geçişi marjinal faydanın vektörel bir büyüklük olarak tanımlanmasıyla gerçekleşmektedir. Kuvvet ve marjinal fayda aynı zamanda vektörlerin toplamına eşittir. Fayda veya faydasızlık, iş ve enerji gibi skaler olarak tanımlanır. Orijinden verili bir noktaya hareket eden bir parçacık tarafından gerçekleştirilen toplam iş, eksen boyunca dirençli güçlerin integrali ile tanımlanırken; iktisadi dünya verili bir durumda varsayılan bireyin toplam faydası veya yararsızlığı mal ekseni boyunca marjinal faydaların integrali ile bulunmaktadır. Toplam enerji, etkili güçlerin integrali olarak tanımlanabilirken; toplam fayda da marjinal faydaların integrali ile ifade edilmektedir. Denge, fiziksel olarak net enerjinin maksimum olduğu noktada veya her eksendeki zit kuvvetlerin birbirlerine eşit olduğu noktada sağlanırken, iktisadi olarak denge tanımlaması kazancın maksimum olduğu noktaya veya her eksendeki marjinal faydaların eşit olduğu noktada gerçekleşmektedir.

Afşar (2013: 128) 19. yüzyıl fiziği ile neoklasik iktisat arasındaki ilişside tüketim teorisinin, fayda kavramının enerji yerine ikame edilmesiyle, enerjinin korunumu yasasından türetildiğini belirtmektedir. Sistemdeki potansiyel ve kinetik enerji toplamının sabitliği, mal düzlemindeki mal miktarlarına çevrilmiştir. Belli bir enerji düzeyinde enerji 
Özyiğit, M. \& İ. Mazgit (2021), "İktisat Fizik Etkileşimi Bağlamında

Ekonofizik ve Gelir Dağılımı", Sosyoekonomi, 29(48), 377-405.

türleri arasındaki dönüşüm, belli bir fayda düzeyinde mal miktarları arasındaki dönüşüme indirgenerek sistemin denge noktası bulunmaya başlanmıştır. Sistemde kinetik enerji, tüketicinin bütçesine karşılık gelmektedir. Klasik mekaniğin iş-güç-enerji konusu, neoklasik ekol tarafından geliştirilen fayda teorisine aynen aktarıldığını ifade etmektedir.

Neoklasik yaklaşımda tüketim, üretim ve bölüşüm gibi iktisadi olgular atomize olmuş bireylerin ${ }^{6}$, sübjektif faydalarını gözeterek gerçekleştirdikleri bireysel kararlar ve seçimler sonucu ortaya çıkmaktadır. Bireysel karar ve seçimler arasındaki ilişkiler ve denge, yalnızca talep ile belirlenen kıtlık fiyatlarının geçerli olduğu, fiyat mekanizmasıyla sağlanmaktadır. Fiyat mekanizması, veri kaynakların optimal dağılımıyla, fayda ve kâr maksimizasyonu hedefleri arasındaki uyumu sağlayarak toplumsal ve iktisadi dengeyi gerçekleştirmektedir. Neoklasik iktisadın temel önermeleri eş marjinallik ilkesi, azalan marjinal getiriler ve tam rekabet koşullarının uygulamasından türetilmiştir. Teorinin çekirdeğinde değişimin ilkeleri ve tüketimin öznel koşulları yer almaktadır. Bu yöntem bağlamında bölüşüm ilişkileri bir faktör fiyatlandırması sorunu olarak ortaya çıkar. Neoklasik okul, fayda yaklaşımından hareketle mal talebine, buradan faktör talebine ve fiyatına yönelerek değişim oranlarının veya fiyatların bölüşümden bağımsız belirlenmesine odaklanmaktadır. Bölüşüm bireyler arasında ve üretim faktörleri arasında ikili bir biçimde belirlenmektedir. Böylece dinamik bir makro analizin yerine mikro-statik ${ }^{7}$ bir analiz kullanılmaktadır. Mikro-statik, kaynakların ve bölüşümün veri olduğu koşullar altında, denge durumunun özelliklerini incelemekte ve farklı denge durumlarını birbiriyle kıyaslamaktadır. Benzer biçimde birikim, bireylerin gelecekteki tüketim ile bugünkü tüketim arasındaki öznel tercihleri sorunu olarak ele alınmaktadır. Birikim ile teknolojik gelişme arasındaki dinamik ilişkiler bu yöntemde statik bir çerçeveye oturtularak, sürekli ikame ve bölünebilirlik ilkeleri bağlamında üretim faktörlerinin göreli kıtlık derecelerine göre sınırsız teknik seçiminin mümkün olduğu bir çerçevede incelenmektedir (Akyüz, 1980: 91-97; Ertuğrul, 2014: 399-401). Neoklasik teori ile iktisadi etkinlik sorunu, veri zamanda kıt kaynakların fırsat maliyetlerini yansıtacak biçimde dağıtılmasına dönüşmüştür. Neoklasik modeller veri zamanda çalışmaktadır; bu anlamıyla modeller zamansızdır. Bireyler, sınıflar olarak değil, faydalarını maksimize edecek biçimde tekil olarak hareket ederler. Fayda maksimizasyonunda marjinal değerler matematiksel olarak türev, integral, diferansiyel ile hesaplanmaktadır. Bu rasyonel bireyler, hiç kimsenin değiştirmeye gerek duymadığı bir genel denge durumuna ulaşmayı hedeflemektedirler (Eren, 2011: 20; Erkan, 2016: 27). Böylece ekonomik değişkenler arasındaki çok sayıdaki ilişkinin çözümlenmesi bir genel denge tasarımı içinde gerçekleştirilmeye başlanmış; iktisadi dünyaya ilişkin

6 Yegorov (2007), sanayi ve piyasa ekonomisinin ortaya çıkışının, tutucu/muhafazakâr politika, kültür ve ekonomiden özgürleşmiş bir bireye ihtiyaç duyması nedeniyle, egemen grupların liberal ekonomiyi topluma empoze etmek istedikleri her zaman bu atomik birey varsayımını ortaya attıklarını belirtmektedir. Ona göre atomistik birey ve rasyonalite düşünceleri, yeni politik düzenin/işleyişin ve yeni ekonomik düzenin/işleyişin meşrulaştırılması biçimindeki yükselen burjuvazinin iki temel ideolojik sorununu çözmektedir. Atomize bireyler varsaymak iktisadi ilişkiler tam bilgiye sahip, rasyonel bireylerin, bă̆ımsız kararları sonucu ortaya çıktı̆̆ını ve tüm sonuçların tikel bireylerin kararlarının tümel bir sonucu olduğunu ifade etmektedir.

7 Walrasgil anlamda ise kuramın genel denge teorisiyle sonuçlanması nedeniyle makro-statik bir analizin kullanıldı̆̆ belirtilmelidir. 
değişkenler nicelikselleştirilmiş ve bu nicelikler, mekanik ve termodinamik analojilerle matematiksel modeller altında ifade edilmeye başlanmıştır (Öziş, 2016: 1244).

\section{3. İktisada Yeni Bir Yaklaşım: Ekonofizik}

Ekonofizik çalışmaları 1990'ların ortasında, fiziğin bir alt dalı olan istatistiksel fizik alanında çalışan bir dizi fizikçinin, ekonominin ve özellikle finansal piyasaların neden olduğu karmaşık problemleri kavrama ve açıklamaya karar vermesiyle başlamıştır. Kavramın ilk ortaya çıkışı H.E. Stanley tarafından 1995 yılında, Kalküta'da düzenlenen "Karmaşık Sistemlerin Dinamikleri" (Dynamics of Complex Systems) konferansında, ekonomi ve fizik alanları arasındaki bir analoji ile gerçekleştiği üzerinde bir uzlaşıdan bahsedilebilir $^{8}$. İktisat ile fizik bilimleri arasındaki 300 yılı aşan etkileşimin tarihine rağmen ekonofizik kavramı yaklaşık 25 yıl önce ortaya çıkmış yeni bir tanımlamadır. Bununla birlikte Schinckus (2011: 148), ekonofizik kavramının ortaya çıkış tarihini, Mandelbrot (1963) ile Mandelbrot ve Taylor (1965)' 'n finansal piyasaların evrimiyle türbülans olgusu arasındaki analojileri kullandıkları çalışmalarına kadar götürmektedir.

\subsection{Ekonofizik Kavramı}

Karmaşık bir sistem olarak iktisadi ilişkiler çeşitli insan davranışlarına ve bireyler arası etkileşimlerin içine, politik, ideolojik ve kültürel düzeylerde gömülü bir yapıdır. Sermaye sahipleri, işverenler, işçiler, tüketiciler diğer taraftan sermaye malları makineler, fabrikalar, araştırma merkezleri bunu yanında doğal kaynaklar, finansal sistem, iletişim ve ulaştırma ağlarının her biri geniş ölçekli karmaşık sistemler ortaya çıkarmaktadır. Tüm bu sistemler, ister iktisadi sistemin doğasından gelen/özünde var olan ve içsel mekanizmaların bir sonucu isterse de çeşitli, iktisadi ilişkilere dâhil olmayan veya dişsal faktörlerin bir sonucu olarak değerlendirilsin, farklı ölçeklerde kalıcı yapısal değişimlerle karakterize olur. Fiziksel bakış açısıyla, cisimler arası net 1sı aktarımının sıfır olduğu (bir sistemin 1sıl, mekanik, radyasyon ve kimyasal dengesinin sağlandığı) termodinamik dengeden uzak bir evrimi göstermektedir. Bu durum bireyler arası iktisadi değişkenlerin de denge durumundan çok belirli bir dinamik dengesizlik halinin varlığını ifade etmektedir. Dolayısıyla mikroskobik ölçekten başlanarak, karmaşık bir sistemin evriminin daha büyük ölçekte, makroskobik düzeyde açıklanması gerekmektedir. Böylesine bir çaba sistemin, makroskobik ölçekte oldukça farklı bir tanımıyla sonuçlanacaktır.

$\mathrm{Bu}$ durumda iki sorun ortaya çıkmaktadır. İlk olarak ilgilenilen olgunun ölçeği, kapsamı açıklığa kavuşturulmalıdır. Ardından az çok kaotik harekete sahip unsurların, makroskobik ölçeklerde belirgin olan kolektif olgulara etkileri gösterilmelidir. Shulz (2003: 2-10) çevrenin yeterince büyük bir kısmının dâhil edilmesiyle karmaşık bir sistemin belirli bir zamanda izole edilebileceğini belirtmektedir. Yalıtılmış sistemin anlık hali, sistemin evrimi için bir başlangıç koşulu olarak kabul edilebilmektedir. Böylece içerilen karmaşık sistemin nicel bir tanımlaması için yeterince büyük bir izole edilmiş sistem elde

8 Ayrica bkz. Stanley H.E. et al (1996), "Anomalous fluctuations in the dynamics of complex systems: from DNA and physiology to econophysics", Physica A, Vol. 224, 302-321. 
Özyiğit, M. \& İ. Mazgit (2021), "İktisat Fizik Etkileşimi Bağlamında

Ekonofizik ve Gelir Dağılımı", Sosyoekonomi, 29(48), 377-405.

edilmektedir. Matematiksel açıdan bakıldığında, karmaşık sistemin gelişimi daha sonra iyi tanımlanmış bir başlangıç problemine gömülü olduğunu ifade etmektedir.

Bu noktada ekonofizik, esas olarak fizikçiler tarafindan açıklanan yasa, geliştirilmiş olan teori ve metotları; belirsizlik, stokastik (olasılıksal) süreçler ve doğrusal olmayan/sapmalı (nonlineer) dinamiklere sahip iktisadi sorunların çözümü amacıyla kullanan disiplinler arası yeni bir araştırma alanıdır. İktisadi gerçekliğin somut tahlili amacıyla, iktisadi neden ve sonuçları fiziksel neden ve sonuçlarla açıklamaya çalışır. Ekonofiziğin temel araçları çoğunlukla istatistiksel fizikten alınan olasılıksal ve istatistiksel yöntemlerden oluşmaktadır. Ekonofizik, istatistiksel fiziğin fikirlerini, modellerini, kavramlarını ve hesaplama yöntemlerini niceliksel ekonomi alanına uygulayan bir disiplinler arası alandir (Mantegna \& Stanley, 2000; Burda vd., 2003: 1; Sharma vd., 2011: 2; Lux, 2008; Rosser, 2008; Carbone, Kaniadakis \& Scarfone, 2007: xii; Bentes, 2010: 3; Schinkus \& Akdere, 2015: 94; Afşar, 2013: 37; Kırer, 2011: 18-20; Ulusoy, 2008: 9). Bu iktisadi sorunlar, finansal piyasaların mikro yapıları ve finansal piyasalarda getirilerin dağılımı, ekonomik şokların dağılımı ve büyüme oranları, finansal balonların ve krizlerin ekonometrisi, firma büyüklükleri dağılımı ve büyüme oranı, teorik makroekonomi alanında gelir ve refah dağılımı ve şehir büyüklüklerinin dağılımı şeklinde sıralanabilir (Chakraborti vd., 2011: 991; Eren: 2011: 23). Coelho (2007: 1) ekonofiziği, borsa fiyatları veya refah dağılımı gibi iktisadi sorunların analizinde istatistiksel fiziğin araçlarının kullanılması ve açıklamalarda fizik kavramlarından yararlanılması olarak tanımlamaktadır. Ekonofiziğin iki temel alana ayrılabileceğini belirtmektedir; i) daha başat olarak gördüğü borsa çalışmaları veya finansal piyasalar ile ilgili çalışmalar, ii) belirli bir toplumdaki servet ve gelir dağılımıdır. Yakovenko (2008: 2), ekonofiziği, istatistiksel fiziğin yöntemlerini ekonomi ve finansın sorunlarını çözmek için uygulayan disiplinler arası bir araştırma alanı olarak tanılamaktadır. Her ne kadar ekonofizik kavramı fiziğin çeşitli bilim dallarına uygulanmasından bir analoji ile türetilmiş olsa da fizik yasalarına tamı tamına uyduğu söylenememektedir. Ekonofizik daha çok istatistiksel fizik alanında geliştirilen matematiksel yöntemlerin, çok sayıda bireyin oluşturduğu karmaşık ekonomik sistemlere uygulanmasıdır. Bu nedenle olasılık teorisinin uygulamasının bir dalı olarak düşünülebilir. Diğer taraftan ekonofizik, iktisadi olguları karmaşık bir sistem olarak ele almaktadır. Karmaşık sistemler, çok değişkenli olmak zorunda değildir. Az sayıda değişkene sahip ve sistem unsurları arasında yoğun bir etkileşim olan sistemler, çok sayıda değişkene sahip ve sistem unsurları arasında düşük düzeyli bir etkileşimin olduğu sistemlere göre çok daha karmaşık olabilir (Lee, 2007: 143). Progogine ve Stengers (1998), karmaşıklığı sistem unsurları arasındaki etkileşim üzerinden değil sistem davranışları üzerinden tanımlamaktadırlar. Karmaşık sistemler gerçekliği, ancak bir süreç olarak betimlenebilir. Ancak bu noktada istatistiksel fiziğin, matematiksel istatistikten odak, yöntem ve sonuçları açısından oldukça farklı olduğu göz önünde bulundurulmalıdır. Schinckus (2010) ekonofiziği, fizik temelli çeşitli kavram ve modelleri ekonomik olgulara uygulayan hibrit bir disiplin olarak tanımlamaktadır. Ayrıca ilk bakışta oldukça geniş çeşitlilikteki fiziksel modellerin iktisada aktarılması olarak görünmesine rağmen, metodolojik/yöntemsel açıdan istatistiksel fiziğin sayısal yöntemlerinin, kavramlarının, modellerinin ve fikirlerinin uygulandığı niceliksel bir yaklaşım olarak değerlendirmektedir. Karmaşık fizik ile ilişkili bir alan olarak ekonofiziğin, karmaşık bir sistem olarak ekonominin içsel mikroskobik 
etkileşimlerinin makroskobik özellikleri ortaya çıkarmasına odaklanan; karmaşık ekonomik sistemlerin makro düzeylerinin ortaya çıkışlarını kurdukları modellerle açıklamaya çalışan, bu ilişkileri ve özelliklerini istatistiksel olarak ifade eden bir araştırma alanı olduğunu vurgulamaktadir.

İktisadi olguların iktisadi bireyler arasındaki etkileşimler sonucu oluşması ve bu etkileşimlerin belirli yasalara bağlı olması, belirli bir somutu oluşturan moleküllerin etkileşimi içinde ele alındığı istatistik mekanik ile benzerlik kurulmasına neden olmuştur. Ekonofiziğin tanımlanması biraz daha genişletildiğinde basit bir analojinin ötesinde, iktisadi olguların incelenmesinde yeni bir kavramsal çatı üretmek ve ortaya çıkan yeni bilim paradigmasının geliştirdiği yöntemleri kullanmanın bir yolunun ekonofizik olduğunu belirtmek mümkündür (Afşar, 2013: 138). Özellikle istatistiksel fiziğin, termodinamiğin 2. yasasından hareketle türettiği tersinmezlik/geriye dönmezlik, entropi (düzensizliğin ölçümü) gibi kavramların iktisada yansıması veya iktisat tarafından içerilmesi heterojen bireyler, doğrusal olmama (nonlinearity), rastlantısal (random), olasılıksal (stokastik) gibi kavramlarla gerçekleşmiştir (Eren, 2011: 22).

Ekonofizik temel olarak modern fiziğin en önemli araştırma alanlarından olan istatistik fizik ve istatistik mekaniği kullanmaktadır. İstatistik fizik, çok sayıda özdeş parçacık veya alt sistem içeren makroskobik sistemlerin ortaya koyduğu karmaşık davranışların fiziksel özelliklerini incelemektedir. Fiziksel olguların açıklanmasında olasılık yöntemlerini kullanan bir yaklaşımdır. Tek bir elektronun özellikleriyle veya davranışlarıyla değil, örneğin Avogadro sayısı kadar (yaklaşık $6.02 \times 10^{23}$ ) parçacık veya alt sistemin oluşturduğu, elektronlardan oluşan sistemin davranışlarıyla ilgilenmektedir. Bu nedenle istatistiksel fizikte, incelenen fiziksel özellikler makroskobik özelliklerdir ve bunlar genelde ortalamalardır. Bir başka deyişle atomik davranışlardan makroskobik sistemlerin özelliklerinin elde edilmesi, istatistik fiziğin konusunu oluşturur. Makroskobik sistemlerin temel özellikleri incelendiğinde bunlar mikroskobik detaylardan bağımsızdır. Termodinamik bağlamında istatistiksel fizik bu makroskobik büyüklükler arasındaki ilişkilere odaklanmaktadır. Böylece istatistik fizik, termodinamiğin, mikroskobik parçacıklar ve onların etkileşimleri ile daha açık anlaşılmasını olanaklı kılmaktadır. Mikroskobik sistemlerde ise, sistemi oluşturan mikro unsurların konumları ve momentumları önem taşımaktadır. Temel nokta ise mikroskobik seviyede/düzeyde sisteme dair detaylar bilinmeden, makroskobik sistemlerin davranışları hakkında bilgi edinilebilmesi ve söz söylenebilmesidir (Afşar, 2013: 138). Örneğin bir su molekülünün temel bazı fizik prensipleriyle davranışı tamamen anlaşılabilmektedir. Ancak pek çok su molekülünün bir araya gelişiyle oluşan su damlası düşünüldüğünde, havanın belirli bir derecede soğumasıyla bu su damlası bir kar tanesine dönüşmektedir. Kar tanesinin altıgen simetrisi, su moleküllerinin kolektif davranışlarının bir sonucu olarak ortaya çıkmaktadır. Bu noktada milyarlarca molekülün bir arada olduğu durumda tek tek her bir parçacığın hareketinden farklı bir organize davranış sergilemektedir. İstatistik fizik böylesi bağlantıları ortaya koymaya ve açığa çıkarmaya çalışmaktadır. Mikroskobik perspektifte ise makroskobik ortalamalar mikro unsurların özellikleri ve etkileşimleri yoluyla elde edilir. 
Özyiğit, M. \& İ. Mazgit (2021), "İktisat Fizik Etkileşimi Bağlamında

Ekonofizik ve Gelir Dağılımı", Sosyoekonomi, 29(48), 377-405.

İstatistiksel fiziğe, iki farklı yaklaşım söz konusudur. Bu bakış açılarından birincisi termodinamiktir. Termodinamik, mikroskobik detaylarla ilgilenmeden, deneysel sonuçlara dayanarak makroskobik değişkenler arasındaki ilişkileri tutarlı matematiksel yapılarla/kalıplarla ifade etmeye çalışan bir teoridir. İkinci bakış açısı istatistiksel mekanik ise, mikro düzeyden makro düzeye taşıyan bir terimdir (Kabakçığlu, 2007: 3-4). Tong (2012: 1) istatistiksel mekaniği, fiziğin mikroskobik yasalarını, makroskobik ölçekte doğanın açıklanmasına dönüştüren bir sanat olarak tanımlamaktadır. İstatistiksel mekanik mikroskobik özellikler/gözlenebilirler ile makroskobik özellikler/gözlenebilirler arasındaki ilişkiyi kurma imkânı vermektedir. Mikroskobik özelliklerden hareketle, makroskobik özelliklerin nasıl ortaya çıktığını anlamaya çalışmaktadır. Bu temel bakış açısının aynı zamanda termodinamiğin deneysel gözlemlere dayalı olarak kurduğu matematiksel yapıyı mikroskobik özelliklerden hareketle yeniden üretmesi gerekmektedir. İstatistiksel mekanikte tüm mikro durumlar aynı enerjiye sahiptir ve olası durumların olasılıkları eşittir (Kabakçıŏlu, 2007: 4-5; Afşar, 2013: 138-140). İstatistiksel mekanik fiziğin hem klasik hem de kuantum mekaniğinin kuralları ile istatistiğin süreç ve ilkelerini birleştiren ve makroskobik sistemlerin, onların mikroskobik bileşenlerinin davranışları ve nitelikleri temelinde, ölçülebilir özelliklerini tahmin etmeyi ve açıklamayı amaçlayan bir dalıdır.

İstatistiksel mekanik, temeli termodinamiğe dayanan, istatistiğin ilke ve yöntemlerini klasik ve kuantum mekaniğinin yasaları ile birleştiren fiziğin bir dalıdır. İstatistiksel mekanik, istatistiksel fiziğin eşitliklerini, kavramlarını ve yöntemlerini kullanarak, termodinamiğin yasalarını olasılıksal olarak yeniden üretmektedir. Ancak termodinamiğin ikinci yasası olan entropi istatistik fizikte deneysel bir sonuçken, istatistiksel mekanikte sistemin mikro düzeyde dağılımının fonksiyonudur. İstatistik mekanik, deney ve gözlemlerle elde edilen makroskobik sonuçların mikroskobik etkileşimler sonucu nasıl oluştuğunun matematiksel altyapısını kurarak, klasik dinamik ve termodinamik prensiplerin birbiriyle uyumlu olduğunu ortaya çıkarmıştır. Makroskobik sistemlerin ölçülebilir özelliklerini, sistemi oluşturan mikroskobik bileşenlerin özellik ve davranışlarına dayanarak açıklamayı amaçlamaktadır. Ancak sistemi oluşturan parçacıkların tek tek davranışlarıyla ilgilenmek yerine, aynı türden çok sayıda parçacığın ortalama davranışlarını inceler. Bu nedenle de olasılık kuramının yasalarından fazlasıyla yararlanmaktadır. Örneğin entropi salt termodinamik bir değişken değil, zamana bağlı tersinmez tüm sistemlerin bir özelliği halini almaktadır (Afşar, 2013: 139-140; Karaoğlu, 2009: 8-15). Toplumbilimlerinde istatistiksel verilerin toplanmaya başlanmasıyla birlikte, istatistikselleştirilmiş fiziği temsil eden istatistik fizik ve mekaniğin iktisat ile ilişkisi de artmıştır. Toplumsal fenomenlerin ortalamalar üzerinden tanımlanması ve/veya açıklanması istatistiksel fiziğin kurucularından Maxwell'in gazların dinamiğini, sistemi oluşturan parçacıkların ortalamaları ile açıklamaya girişmesine sebep olmuş ve istatistik fizik bir bilim dalı olarak belirmeye başlamıştır (Afşar, 2013: 139).

İstatistik mekaniğin iktisadi ilişkilere bütünsel bir biçimde ilk uygulaması, politik iktisadın temellerine ilişkin olarak deterministik olmayan bir sistem oluşturmaya çalıştıkları Farjoun ve Machover'in (1983) çalışmasıdır. Çalışma kâr oranı üzerine yoğunlaşmış ve kâr oranları, içsel bir olasılıksal yasaya göre rastlantısal (random) hareket eden bir değişken olarak ele alınmıştır. İstatistiksel bir değişken olarak tanımlanan kâr oranı, istatistik 
mekaniğin analiz araçlarıyla incelenmiştir. Hem Marksist hem de neoklasik iktisatta kâr oranlarının eşitlenme eğilimi çerçevesinde, iktisadi aktörlerin etkileşim hızlarındaki farklılık göz önüne alınarak kapitalist ekonomilerde her sektörde aynı kâr oranının ortaya çıkmayacağı sonucu elde edilmiş, kadim iktisadi sorunsallardan olan toplulaştırma sorunsalına farklı bir yanıt üretilmiştir.

Cockshott vd. (2009: 139-147), iktisadi olguların ele alınmasında matematiksel denge yerine, istatistik mekanikte kullanılan istatistik dengenin devreye sokulmasının daha gerçekçi sonuçlar üreteceğini ileri sürmekte ve kurdukları analojilerle, istatistiğin iktisatta kullanımında yeni bir araştırma alanı önermektedirler. Kurdukları analojilerden biri temel bir ekonomi ile ideal gazlar arasındadır ve bu iki farklı olgu arasında önemli benzerlikler bulunmaktadır. Gaz moleküllerinin bulunduğu kabı, belirli iktisadi ilişkilerin oluşturduğu yapı olarak nitelemekte ve gaz moleküllerini de bu iktisadi ilişkilere tabi olarak bireyler olarak tanımlamaktadırlar. Kapalı kaptaki moleküllerin birbirleriyle çarpışması sonucu gerçekleşen enerji transferlerini de değişim sonucu gerçekleşen gelir veya refah transferleri olarak modellemektedirler. Böylece belirli koşullar ve sınırlar altında, etkileşimler sonucu gerçekleşen durumun iktisadi analojisiyle, gerçek iktisadi ilişkilerin açıklanması arasında bir benzerlik kurarak modellemektedirler. Mimkes (2006), termodinamik yasalarını iktisat için üretme girişiminde bulunmuştur. Enerjinin korunumu ilkesi olan termodinamiğin 1. yasası, iktisatta üretimin sermaye dengesine karşılık gelmektedir. İktisadi artık, artığı elde etmek için gerekli sermaye stoku değişimi ile iş için gerekli olan girdilerin farkına eşittir. Termodinamiğin ikinci yasası olan entropi ise üretim fonksiyonuna karşılık gelmektedir.

\subsection{Ekonofiziğin İktisada Olası Katkıları}

İktisat ve ekonofizik etkileşiminde çeşitli katkı noktaları söz konusudur. İlk olarak ana akım iktisadın veriye dayalı yöntemleri, belirli bir sistemin yapısal eşitliklerinin tanımlanmasında parametre katsayılarında önsel kısıtlar gerektirmektedir. Ayrıca ekonomi teorisinde biçimlendirilmiş sistemlerin başlangıç koşullarının oluşturulmasıyla ilgili olarak model, gerçek fenomen hakkında a priori (önsel) bir hipotez olmaktadır. Böylece ampirik yöntem, ekonomik gerçeklere referansla varsayımsal olarak tanımlanan a priori bir ilişkiyi ifade etmektedir. Schinkus ve Akdere'ye (2015: 92-4) göre özellikle ekonometrik çalışmalar, test edilmek istenen iktisadi teorilerden türetilebilecek aşamaların, katsayıları veya değişkenlerin parametrelendirilmesini gerektirmektedir. Böylece i) iktisadi analizin olasılıksal etkileri ve ii) dengenin örtük varlığı konusunda, iktisat teorisiyle bağlantılı olarak gerçekleştirilen, temel varsayımlar ekonometrik olarak bütünleştirilmiştir. Zaman serileri tahminlerinde, ekonometrisyenler, değişkenliklerini başka bir dağılımla açıklayan bir ana eğilimin varlığı ile ilişkili olan denge düşüncesinin tanımlanmasında temelde Brownian hareketi (Gausyen yapıda) kullanıldığını ifade etmektedirler. Bu bağlamda ekonometri temelde Gausyen eğilimlerin varlığ varsayımı üzerine kuruludur. Anormal verilerin (Gausyen dağılımın dışındaki veriler) tespit edilmesi durumunda veri madenciliğine başvurarak, beklenen ortalamaların sıfır olmasını sağlamaktadır. Bu durum ekonometrinin, iktisadi olgular açısından belirli bir a priori (önsel) davranış varsaydığını göstermektedir. Ancak yöntemsel olarak ekonofizik ise istatistiksel mekaniğin, kompleks (karmaşık) sistemlerin makroskobik evrimlerinin ve davranışlarının istatistiksel olarak açıklanmasına 
genişletilmesi olarak tanımlanabilir (Yakovenko, 2008). Bu nedenle ekonofizik açısından anormal veriler söz konusu değildir. Bunlar yalnızca gerçeklikle ilişkili veriler olarak ele alınırlar ve yöntemsel bir a priori-ism'den (ön varsayımcılıktan) kaçınmaktadırlar. Ekonometrisyenler fiyat değişikliklerinin sıfıra yakın kurtosis (mezokurtik dağılım) ile lognormal olasılık dağılımına uyduğunu varsaymaktadır. $\mathrm{Bu}$, a priori (önsel tanımlı) bir bakış açısı, büyük dalgalanmaların küçük bir olasılığa sahip olduğunu ima eder. Oysa gerçek veriler, pozitif kurtosis ve aşırı olayların meydana gelme ihtimalinin daha yüksek olduğu leptokurtik dağılım göstermektedir (Mandelbrot, 2004). Bu durum ekonofizik çalışmalarının, iktisadi incelemelere temel katkısının bulunduğu alan olarak değerlendirilmektedir.

Gallelati vd. (2006: 2) ekonofizik uygulamalarına ilişkin eleştirilerini dört başlik altında sıralamaktadırlar. Öncelikle ekonofizik çalışmalarının, iktisat teorisi içindeki gelişmelere karşı duyarsızlığını belirtmektedirler. Bu duyarsızlık ekonofizik analizlerinin özgün ampirik bulgulara ulaşmalarına karşın yapılan analizlerin aynı veya benzer ampirik sonuçlarının iktisat teorisi içinde zaten var olduklarını görmemelerine neden olmaktadır. Diğer taraftan evrensel ampirik düzenliliklerin ekonomik faaliyetlerin birçok alanında bulunabileceği inancını da eleştirmektedirler. Bir bağlamda ekonofiziğin iktisadi ve sosyal ilişkilerin işleyişini kavramayı geri planda bıraktıkları anlamına gelmektedir. Ayrıca ekonofiziğin gelişimi bağlamında daha titiz ve sağlam istatistiksel yöntemlere olan direnç ve ampirik olayları açıklamak için kullanılan teorik modellere ilişkin de endişelerini ifade etmektedirler.

Schinckus (2011: 150-156), finansal iktisat ile ekonofizik arasındaki temel farklılıkları veya ekonofiziğin katkılarını üç temel ayrım üzerinden tanımlamaktadır. Bunlardan birincisi ampirik yaklaşım ile ampirist yaklaşım olarak tanımlanmaktadır. Ampirik yaklaşım olarak nitelediği finansal ekonomi temel olarak sınırlı alanlar Gauss dağılımına dayanmaktadır. Merkezi Limit Teoremine dayalı olarak veri setleri Gausyen dağılım gösterebilmektedir. Ancak bu sonsuzda gerçekleşmektedir. Ekonofizik yaklaşım açısından, Gauss çerçevesinin asimptotik gerekçesi, finansal iktisatçıların finansal çöküşlerin gerçekleşmesini hafife almasına veya eksik tahminlemesine neden olan önsel bir düşüncedir. Bu nedenle ekonofizik, deneyler sonucu ortaya çıkan bilgiyi olduğu gibi kabul etmekte ve modellerini bu verileri temel alarak kurmaktadır. Ampirist yaklaşım ise tüm hipotezlerin ve teorilerin yalnızca a priori bir akıl yürütmeye veya sezgiye dayanmak yerine doğal dünyanın gözlemlerine karşı test edilmesi gerektiğini savunmaktadır ve bu bağlamda ekonofiziği ampirist yaklaşım olarak ifade etmektedir. İkincisi mikro perspektif ile makro perspektif arasında kurulmaktadır. Finansal piyasaların matematiksel modellenmesinde benzer atomistik varsayımları her iki yaklaşımın da benimsemesine rağmen finansal iktisatçıların bireylerin karşılıklı etkileşimlerini göz önünde bulundurmadan davranışlarını analiz ettiğini ve tamamen rasyonel birey varsayımı altında çalıştıklarını belirtmektedir. Bu görüşe karşıt olarak, ekonofizik, etkileşimli atomistik bir yaklaşıma dayanmaktadır. Çünkü makroskobik olaylara sahip olmak için parçacıklar arasındaki etkileşimleri niteleyen özelliklere odaklanmaktadır. Böylece tüm etkileşimleri dikkate aldıklarını belirtmektedir. Benzer bir vurgu Schinckus ve Akdere'nin (2015) çalışmasında da mevcuttur. Neoklasik iktisat içinde rasyonelliğin özsel bir nedensellik olarak ortaya çıktığını ve birey 
davranışlarını belirlediğini ifade etmektedirler. $\mathrm{Bu}$ perspektifte, tüm makro-fenomenler, birlikte/planlı bir biçimde hareket eden birçok nedenin toplam etkisinin, tek başına hareket eden sebeplerin her birinin etkisinin toplamı ile aynı olan bir nedensellikten kaynaklanmaktadır. Ekonofizik, rasyonel-birey teorisiyle ilgilenmemektedir. Sistem daha çok makro düzeyde gözlemlenebilip analiz edilebilmektedir. Son olarak ekonomik dengeye karşılık ekonofizik yapı arasında bir ayrım tanımlamaktadır. İktisadi denge farklı iktisadi ekollere göre farklı anlamlar ifade etmekle birlikte Schinckus ve Akdere (Walrasyan temelli Arrow-Debreu tarafından geliştirilmiş) neoklasik denge kavramından hareket etmektedir. Neoklasik finansta kullanılan denge kavramının, ekonomik sistemleri oluşturan unsurların homojenliğini öngören metodolojik bireyciliğe dayandığını ifade eder. Böylece denge genellikle aynı beklentilere sahip olduğu düşünülen bireylerin homojen maksimize edici davranışlarının eklenmesinden kaynaklanır. Dolayısıyla ekonomik aktörler arasındaki kompleks etkileşimler dikkate alınmamaktadır. Etkileşimlerin parçacığın konumuna bağlı olduğu düşünüldüğünde, ekonofizikçiler ekonomik sistemlerde heterojenliğin önemini vurgulamaktadırlar. Bu heterojenlikten karmaşık bir durumun ortaya çıkabileceğini göz önünde bulundurarak, ekonofizik, çoklu nedenlerin ortak eyleminin, bireysel olarak hareket eden nedenlerin etkisinin toplamı olmadığı bir nedensellik sağlar. Ekonofiziğin dengede olmayan stokastik dinamikleri temel aldığını ve dengenin olduğuna dair bir kanıt görmediğini belirtir. Farklılıklar her ne kadar finansal verilere, iktisat ve ekonofizik uygulamaları arasındaki ayrımlar üzerinden ifade edilse de aynı ayrımlar, iktisat ve ekonofiziğin toplumsal ilişkileri analiz etmedeki yöntemsel farklılıkları için de kabul edilebilir.

Dolayısıyla ekonofizik, iktisadi sistemleri olgusal olarak analiz ederek bu sistemlerin dinamiklerini, mikroskobik düzeydeki oldukça fazla sayıda heterojen etkileşimin makro sonuçları biçiminde kavramaktadır. Karmaşık sistemlerdeki aşırı (uç/limit) değişimlere odaklanmaktadır. Bu nedenle gözlenen verilerle başlayarak, finansal çöküşler/krizler gibi aşırı olayların meydana gelebileceği modeller geliştirmektedir. Ekonofizik, istatistiksel özelliklerin evrenselliği üzerine kuruludur. Güç yasaları (Power Law), etkileşen parçaların davranışının makro sonucu olarak görülebilir. Bu etkileşimler mikroskobik detaylardan bağımsızdır ve sadece birkaç makroskobik parametreye bağlıdır. Güç yasaları, ortaya çıkan özelliklerdir çünkü nedensel olarak ortaya çıkmazlar ve bileşenlerin özelliklerinin toplamına indirgenemezler. Gözlemleri istatistiksel olarak güç yasasıyla tanımlanabilen aşırı değişimlerin varlığı incelenmektedir. Bu yapıların özellikleri, istatistiksel biçimlerine referansla Lévy süreci ${ }^{9}$ olarak tanımlanan güç yasasıyla ifade edilmektedir. Dolayısıyla ekonofizik yöntem olarak iktisadi sistemleri, istatistiksel makro-kalıpların (modellerin) belirlenmesi yoluyla olgusal olarak tanımlanmasına odaklanmaktadır. $\mathrm{Bu}$ bağlamda ekonofizikçiler tarafından tanımlanan dünyada Gausyen etkiler söz konusu değildir. Daha leptokurtik bir dağılımın kullanılmasıyla uç (aşırı/limit) olayların önemli bir ortaya çıkma

9 Lévy süreci, durağan ve bağımsız artışlarla (fark değişikliklerle) zaman stokastik (olasıllısal) bir süreçtir. Lévy, Gauss'un istatistiksel yapısını, birikimleri bağımsız ve durağan olan ve $P(X>x)=x^{-\alpha}$ biçimindeki gü̧ yasasını takip eden, yeni bir dağıllım sinıfi geliş̧tirmek üzerine çalışmış̧ır. Bu durum bir değişkenin olasılığının x'ten büyük olması halinde bozulma yasasını izlediğini ifade eder. Bu denklemde, a, güç yasasının karakteristik üssüdür (bu parametre, potansiyel değişikliklerin duyarlılığına işaret ettĭgi için bir istikrar göstergesidir). 
ihtimalinin olduğunu bulmaktadırlar. Böylece ekonomideki uç (aşırı/limit) olayların dikkate alınması, Gaussyen çerçevenin istikrarı sağladığı durumlarda, uç (aşırı/limit) olayların ortaya çıkmasını çok olanaksız kılmaktadır. Ekonofizik yaklaşımda karmaşık sistemlerden kaynaklanan potansiyel aşırı olaylar göz önünde bulundurulmaktadır.

Verili bir sistemde, iktisadi birimlerin karşılıklı etkileşimleri için mikroskobik denklemler yazmak neredeyse imkânsızdır. Bu noktada istatistiksel fiziğin stokastik dinamikler, kısa-uzun dönemli korelasyonlar, benzerlik, ölçeklendirme gibi kavramları, sistemin mikroskobik tanımlamalarına çözüm üretmeksizin, aynı ekonomik sistemin küresel davranışlarının anlaşılmasını olanaklı kılmaktadır (Sharma vd., 2011: 2; Mantegna \& Stanley, 2000). Klasik iktisat, rasyonel bireyler, görünmez el, piyasaların etkinliği vb. pek çok aksiyom haline gelmiş sınırlayıcı varsayımlar üzerine kuruludur. Ancak gerçekte piyasalar varsayıldığı kadar etkin değildir. Bireyler kısa döneme aşırı odaklanmış ve uzun dönem açısından kör/öngörüsüz olabilmekte veya uzun dönemi iktisadi motivasyonlarının oluşumunda dikkate almayabilmektedirler. Toplumsal baskılar ve düzensizliklerle güçlenen sapmalar/hatalar kitlelerin kolektif irrasyonel davranışlarına neden olabilmektedir (Sharma vd., 2011: 2). Bu bağlamda ampirik gözlemlerin matematiksel modellerle uyumsuz hale gelmeleri modellerin yenilenmesini veya tümüyle terk edilmesini gerektirmektedir. Diğer yandan insan davranışlarını modellemek, doğa yasalarını modellemenin yanında neredeyse imkânsız olsa da istatistiki düzenliliklerin ortaya çıktığı geniş nüfus kitlelerinin davranışlarını incelenmesi ekonofiziğin kullandığı yöntemler açısından mümkündür. İktisat ve ekonofizik arasındaki etkileşimin ayrışma noktaları bu biçimde özetlenebilir.

\section{Ekonofizik Çerçevesinde Gelir Dağılımı}

Gelirin ve servetin insanlar arasında eşit bir biçimde dağıldığg bir toplum veya ülkeden söz etmek neredeyse imkânsızdır. Bu bağlamda başta iktisat olmak üzere sosyal bilimlerin oldukça geniş bir alanı eşitsizlik ile gelir ve servet dağılımları konusunda bilgi üretmektedir. Bu durum refahın nasıl dağıldığı, dağılım fonksiyonunun biçiminin ne olduğu, bu dağılımın evrensel bir olgu mu yoksa belirli bir ülkenin özgün koşulları sonucu mu ortaya çıktığı, zamana veya tarihe bağlı olup olmadığı gibi bir dizi zor sorunun ortaya çıkmasına neden olmaktadır (Richmond vd., 2006: 131; Chakrabarti vd., 2013: 1). Ana akım iktisat gelir dağılımının uç durumları (tüm bireyler arasında eşit veya tam olarak eşitsiz dağıldığı) dışında log-normal dağılıma uyumlu olarak dağıldığını ileri sürmektedirler. Diğger taraftan log-normal dağılımın, dağılımın uç kısımlarını açıklamadaki yetersizliği çalışmaların yönünü değiştirmiştir. Bir ülkedeki gelir dağılımının tek bir dağılım biçimiyle açıklanamayacağının ortaya çıkışıyla, ekonofiziğin, iktisadi problemlere fizik yöntemlerini kullanarak çözümler araştırdığ literatürü bu noktada kesişmektedir (Kırer \& Eren, 2012: 2021).

Gelir ve servet dağılımı ile ilgili çalışmaların Pareto’nun (1897) “Cours d'Économie Politique" adlı yaklaşık yüz yirmi yıl önce gerçekleştirdiği ve bütün ülkeler ve tüm zamanlar için geçerli olan, gelir dağılımını yöneten bir yasa ortaya koyma çabasıyla başladığı söylenebilir. Avrupa için gerçekleştirdiği ve toplumun zengin kesimi için servet dağılımının, sonradan Pareto Yasası olarak bilinecek olan, Güç Yasası Kuyruğu (Power Law Tail) 
izlediğini ortaya koymuştur. Schinckus (2011: 150) güç yasasını, etkileşim içindeki çok sayıda bileşenin / ekonomik aktörün daha düşük düzeylerden davranışlarının bir makro sonucu olarak görülebileceğini belirtmektedir. Bütün bu etkileşen parçaların, her mikroskobik detaydan bağımsız ve sadece birkaç makroskobik parametreye bağlı olan kanunlara uyduğu tespit edilmiştir. Ayrıca ölçekleme yasaları ortaya çıkan özelliklerdir, çünkü nedensel olarak ortaya çıkmazlar ve özellikleri bileşenlerin toplamına indirgenemez. Gini (1922) aynı veriler üzerinden güç yasasının geçerli olduğunu ancak güç yasasının kuvvet değerinin ülkeden ülkeye farklılaştığını ifade etmiştir. Montroll ve Shlesinger (1983) ise 1935-36 yılları için ABD ekonomisinin kişisel gelir verilerini incelemişler ve en üst $\%$ 1'lik gelir grubu için -1,63 kuvvet değeriyle güç yasasının geçerli olduğunu ancak geriye kalan ücretliler olarak adlandırılabilecek kesim için gelirin log-normal dağılım biçimine sahip olduğunu belirtmişlerdir. Pareto'dan ayrı olarak Gibrat (1931) aynı problem üzerinde çalışmış ve orantılı etki yasasını ileri sürmüştür. Champernowne (1953) ise aynı sorunla ilgili olarak Pareto'nun iddialarının değerlendirilmesi amacıyla olasılık teorisini ileri sürmüştür (Clementi \& Gallegati, 2005: 3; Aoyama vd., 2000: 2).

Pareto dağılımına ilişkin dört temel model söz konusudur. Ancak temel iki model literatürdeki pek çok çalışmada açıklayıcı ve işlevsel olarak kullanılmıştır. Pareto'nun temel modeline göre eğer $\bar{F}(x)$, belirli bir toplumdaki x'ten fazla geliri olan bireylerin oranını ifade ederse, $x$ 'in geniş değerleri için yaklaşık olarak aşağıdaki eşitliği elde edilmektedir ${ }^{10}$;

$$
\begin{aligned}
& \bar{F}(x)=C x^{-\alpha} \\
& \text { veya } \\
& \log (\bar{F}(x))=\log (C)-\alpha \log (x)
\end{aligned}
$$

Bu eşitlik klasik Pareto dağılımını ifade etmektedir. Belirli bir düzeyin üzerinde gelir elde eden bireylerin sayısının logaritması ile bu gelirlerin logaritmasının grafiği çizildiğinde elde edilen noktalar, $\log (\mathrm{x})$ değerlerinin bulunduğu eksenle - $\alpha$ eğimine sahip düz bir çizgi olacaktır. Bu $x^{-\alpha-1}$ 'e orantılı yoğunluk fonksiyonuyla bir dağılımı ifade etmektedir. Pareto, gözlemlerine dayanarak bu $\alpha$ açısının çeşitli ülkeler açısından küçük farklılıklara rağmen 1,5 değeri etrafında olacağını belirtmektedir. Diğer taraftan nüfusun veya gelir veya servetin tanımlanmasındaki değişimlere rağmen $\alpha$ katsayının neredeyse sabit olduğunu ileri sürmekteyse de bu iddiasında ısrarcı değildir. Bu nedenle servet dağılımında daha karmaşık olan aşağıdaki modeli oluşturmuştur;

$$
\bar{F}(x)=C(x+b)^{-\alpha_{e}-\beta x}
$$

Ancak Pareto dağılımının, bütün gelir aralığı üzerinden gözlemlenen veri frekansına zayıf bir uyum gösterdiği, genellikle yüksek gelir düzeylerinin dağılımına uygun olduğu uzun bir zamandır kabul edilmektedir. Mandelbrot, Pareto Yasasını üç farklı biçimde

10 Matematiksel notasyon ve eşitlikler için bkz. Richmond vd. (2006), "A Review of Empirical Studies and Models of Income Distributions in Society", Econophysics and Sociophysics, Trends and Perspectives içinde, (eds.) Bikas K. Chakrabarti, Anirban Chakraborti, and Arnab Chatterjee, Wiley-VCH Verlag GmbH \& Co. KGaA. 
tanımlamaktadır. Eğer $\Pi(\mathrm{m})$, m düzeyinden daha yüksek gelire sahip bireylerin yüzdesi olarak tanımlanırsa, Güçlü Pareto Yasasını şu biçimde ifade etmektedir;

$$
\Pi(m)= \begin{cases}\left(m / m_{0}\right)^{-\alpha}, & m>m_{0} \\ 1 & , m<m_{0}\end{cases}
$$

Burada $m_{0}$ bir ölçek faktörüdür ve $\alpha$ 'nın değeri belirlenmemiştir. Pareto Yasasının en güçlü biçiminde $\alpha$ değeri, Pareto'nun orijinal verilerinde $\alpha$ 'nın ortalama değeri olan, $\alpha=3 / 2$ değerine eşittir. Ancak son çalışmalar daha geniş bir dağılımla $\alpha$ değerinin ortalamasının 2 değerine yaklaştığını göstermektedir. Bu durum, güç yasasının yalnızca $m \rightarrow \infty$ limitinde geçerli olduğu Zayıf Pareto Yasasına işaret etmektedir. Başka bir ifadeyle $\alpha$ 'nın değerinin tanımlanmamış olduğu koşullarda;

$$
\Pi(\mathrm{m}) /\left(m / m_{0}\right)^{-\alpha} \rightarrow 1, m \rightarrow \infty
$$

biçiminde ifade edilmektedir. Günümüzde ise Pareto Yasası, kümülatif dağılım fonksiyonu (CDF) yerine olasılık yoğunluk fonksiyonu (PDF), P(m) açısından ele alınmaktadır.

$$
\begin{aligned}
& \Pi(\mathrm{m})=\int_{m}^{\infty} P(m) d m \\
& P(m) \sim m^{-(1+\alpha),} \quad \text { yüksek } m \text { düzeyi için }
\end{aligned}
$$

Bu noktada Pareto'nun topluma bakış açısı, analizi ile ilgili önemli çıkarımlar sağlamaktadır. Pareto kuyruğunun davranışını açıklamaya yönelik Champernowne (1953) bireysel gelirlerin evrimini modellemek için Markow zincirini, Mandelbrot (1960) ise durağan Lévy dağılımını kullanmıştır (Reed, 2003: 469; Arnold, 2015: 1). Son zamanlarda modern verilerle kapitalist ekonomiler için gerçekleştirilen kayda değer araştırmalar da gelir dağılımının üst kuyruğu için (genel olarak toplam bireylerin \%5'inden az) gerçekten de yukarıdaki davranışı takip ettiğini göstermiştir. Diğer taraftan eğimlerdeki ülkeden ülkeye veya zamandan zamana bulunan farklılık göz ardı edilemeyecek kadar büyüktür. Bu nedenle gelir dağılımının niteliği ve anlaşılması hala bir problem olarak ortada durmaktadır. Bu noktada açıklanması gereken esas sorun ise fonksiyonel biçimin nüfusun büyük çoğunluğu için gelir dağılımının güç yasası kısmına uyumlu olmamasıdır. Son dönemlerde gerçekleştirilen pek çok çalışma nüfusun düşük-orta gelir aralığı için gelir dağılımının fonksiyonel biçiminin exponansiyel veya azalan log-normal dağılıma uyduğunu göstermektedir (Clementi \& Gallegati, 2005: 4). Chakrabarti vd. (2013: 1-2) gelir ve servet dağılımının esas gövdesinin log-normal ve gama dağılımına oldukça uygun olduğu belirtmektedir. İktisatçılar genellikle log-normal dağılımı tercih ederken, istatistikçiler veya son dönemde ekonofizikçiler gama dağılımı (olasılık yoğunluğu için) veya Gibbs/exponansiyel dağılımı (kümülatif dağılım için) gibi alternatif dağılım biçimlerine daha fazla güvenir gözükmektedirler. Dağılımın üst kısımları yani dağılımın kuyruğu, Pareto tarafından ortaya konulan güç yasasıyla veya Pareto Yasasıyla oldukça iyi biçimde ifade edilmektedir.

Souma ve Nirei (2005: 34-39) de gelir ve servet dağılımında güç yasası dağılımının Pareto tarafından ortaya konulmasının ardından Gibrat tarafından, güç yasası dağılımının 
yalnızca yüksek servet ve gelir aralığı için geçerli olduğunu; diğer gruplar açsından dağılımın log-normal biçimde gerçekleştiğini belirtmektedirler. Yine bugün için yüksek gelir aralığında güç yasası dağılımı geçerli iken dağılımın diğer kısmı açısından sabit, belirlenmiş bir dağılımın bulunmadığını ve son zamanlarda üstel (exponential) veya Boltzmann dağılımlarının önerilmekte olduğunu belirtmektedirler. Japonya ekonomisindeki gelir verilerini kullanarak gerçekleştirdikleri çalışmalarında orta ve düşük gelir aralığı için dağılımın log-normal dağılıma uygun olduğunu diğer taraftan yüksek gelir grubu için dağılımın güç yasası dağılımını izlediği ve Pareto endeksinin $\alpha=2$ etrafında dalgalandığını tespit etmişlerdir. Ayrıca yüksek gelir grubu açısından gelir kaynakları ücretler ve sermaye kazançları iken yüksek gelir grubu dışarıda tutulduğunda temel gelir kaynağının yalnızca ücretler olduğu çalışmanın bir diğer sonucudur. Clementi ve Gallegati (2005) ABD, Birleşik Krallık ve Almanya için çeşitli yılları kapsayan gelir dağılımını inceledikleri çalışmalarında, gelir dağılımı için iki rejimin bulunduğunu ortaya koymuşlardır. Düşük ve orta sınıf açısından (toplam nüfusun \%97-\%99'u) gelirin iki parametreli log-normal dağılım fonksiyonu ile uyumlu dağıldığını, diğer taraftan gelir dağılımının üst-uç kuyruğu (toplam nüfusun \%1-\%3’ü) için ise gelirin güç yasasına veya Pareto yasasına uyumlu bir dağılım sergilediğini göstermişlerdir. Yakovenko ve Silva (2005) ABD ekonomisi için gerçekleştirdikleri çalışmalarında kişisel gelir dağılımının iki sınıflı bir yapıyla tanımlanabileceğini ortaya koymaktadırlar. Çalışmalarında nüfusun alt sınıfa ait olan büyük çoğunluğu açısından (\%97-99) gelirin exponansiyel Boltzmann-Gibbs (termal) dağılıma, üst sınıf açısından (\%1-3) ise Pareto güç yasası (termal-üstü/superthermal) dağılımına sahip olduğunu göstermişlerdir. 1983-2001 yılları arasında gelir verilerini incelediklerinde "termal" kısmın zamana göre durağan olduğunu ancak "termal-üstü" kısmın borsayı takip ederek dalgalandığını (genişleyip/şişip-daraldığını/büzüldügünü) elde etmişlerdir. Fujiwara (2005: 24-25) kişisel gelir ve firma ölçeği verileri üzerinden gerçekleştirdiği çalışmasında, gelir dağılımının ve firma ölçeğinin/büyüklüğünün üst kuyruğunun güç yasasına (Pareto ve Zipf) uyumlu olduğunu ve bu bölgede büyüme oranının gelir veya firma ölçeğinin başlangıç değerinden bağımsız olduğunu ispatlamıştır. Kişisel gelir ve refahı her bir hane halkı için akım ve stok değişkenler olarak ele alan çalışmada yüksek gelir dağılımının güç yasasını izlediği; diğer taraftan düşük veya orta gelir dağılımının log-normal, Boltzmann veya diğer fonksiyonel dağılım biçimlerine uyması gerektiği belirtilmektedir. Pareto yasasındaki kuvvetin bireysel gelir dağılımı için 2, firma ölçeği için ise 1 değeri etrafında olduğunu belirtmektedir. Bu nedenle kuvvetin 1'e eşit olduğu biçime Pareto-Zipf yasası dağılımı adını vermektedir. Firma ölçeklerinde de gelir dağılımı ile benzer bir dağılımın gözlendiğini vurguladığı çalışmasında, dağılım yasasının kökenlerini anlamanın, tüketim, iş çevrimleri ve diğer makro ekonomik faaliyetlerle olan bağlantısı nedeniyle oldukça önemli olduğunu vurgulamaktadır. Çünkü Pareto-Zipf yasasının geçerli olduğu aralıkta, dağılımın üst kuyruğundaki, yüzde bir kaçlık kesimde bireylerin veya firmaların küçük bir kısmının toplam gelirin büyük bir miktarını işgal ettiği gözlenmektedir. Bu koşullarda küçük özgün şoklar, dikkate değer makro ekonomik etkilere yol açabilmektedir. Shaikh (2018: 1) ekonofiziğin “iki sınıf” (econophysics "two classs” Approach - EPTC) yaklaşımıyla dünya gelir eşitsizliği verilerini (World Income Inequality Database - WIID) kullanarak gerçekleştirdiği çalışmasında ücret gelirlerinin üstel dağılım sergilerken mülkiyet gelirlerinin Pareto dağılımı gösterdiğini bulgulamıştır. Chatterjee vd. (2005: v) kültürel veya 
tarihsel farklılıklara rağmen belirli bir düzeye kadar farklı ülkeler tarafından izlenen iktisat politikalarında gelir ve servet dağılımının belirli bir evrensel yapıyı/modeli takip ettiğini belirtmektedirler. Jenkins (2016) Birleşik Krallık için 1990'ların ortalarından itibaren eşitsizlik düzeylerini ve eğilimlerini incelediği çalışmasında toplumda zenginler için vergi gelirlerini ve zengin olmayanlar içinse hanehalkı bütçe araştırmaları verilerini kullanmaktadır. Üst gelir gruplarının incelenmesi açısından vergi gelirlerinin Pareto dağılımına uyumlu olduğunu, dönemin bütünü açısından ise gelir eşitsizliğinin Gini katsayısı üzerinden tahminlenmesine dayanarak yükseldiğini belirtmektedir. Farklı eşitsizlik endekslerinin, gelir dağılımının farklı bölümlerindeki gelir farklılıklarının nasıl değerlendirileceğine ilişkin farklı varsayımlar içerdiğini belirtmekte ve eşitsizliklerin incelenmesinde normatif kararların devam eden önemini vurgulamaktadır. Türkçe literatürde, tespit edilebildiği kadarıyla, ekonofizik ve gelir dağılımı ilişkisini konu edinen tek çalışma Kırer (2011)'in “Türkiye ve Almanya’nın Kişisel Gelir Dağılımına Ekonofizik Yaklaşım” başlıklı doktora tezidir. Çalışmada Türkiye için gelir ve yaşam koşulları anketi Almanya için ise Alman sosyoekonomik panel çalışmasının verilerinden yararlanılarak ekonofiziğin istatistiksel yöntemleriyle iki ülkenin gelir dağılımları karşılaştırmalı olarak analiz edilmiştir. Çalışmada her iki ülke için de nüfusun \%1-2'lik bir kısmının kişisel gelir dağılımlarının genelleştirilmiş Pareto dağılımıyla uyumlu iken geri kalan kısmının farklı dağılımlara uyumluluğu incelenmiş ve gamma dağılımına uyumlu olduğu bulunmuştur. Ayrıca iktisadi olarak her iki ülkenin nüfusunun çok düşük bir kısmını oluşturan yüksek gelirliler ile çok büyük bir kısmını oluşturan düşük ve orta gelirliler arasında keskin bir ayrımla ayrıştığı sonucuna varılmıştır. Kırer'e (2012: 22-23) göre gelir dağılımı ile ilgili geliştirilen teoriler daha çok kişisel ve fonksiyonel gelir dağılımlarını temel almaktadır. Diğer taraftan gelişmiş ülkeler açısından milli gelir büyümesi; gelişmekte olan ülkeler açısından ise iktisadi büyümenin gerçekleştirilememesi kişisel gelir dağılımına olan ilgiyi artırmıştır. $\mathrm{Bu}$ durum aynı zamanda ekonofizik çalışmalarının gelir dağılımı alanına yönlenmesinin temel nedenlerinden biri olarak ifade edilmektedir.

Sonuçta refah ve gelirin ampirik dağılımı bazı açılardan üretim, bölüşüm ve yeniden bölüşümün bütününü yansıtmaktadır. Servet dağılımını karmaşık iktisadi etkileşimlerin bir sonucu olarak değerlendirdikten sonra fizik odaklı yaklaşımların temel katkılarını şöyle siralamaktadir;

i. Ulaşılabilir veriye sahip ülkelerin neredeyse tümü için servet dağılımının evrensel özelliklerinin açık bir tanımlaması açısından Gibbs-Boltzmann (veya Gama) dağılımı verilerin esas kısmı için geçerli olup uç kısım için belirli bir Pareto kuyruğu bulunmaktadır. Dolayısıyla gelir dağılımının yapısında neredeyse tüm ülkeler açısından iki sınıfın bulunduğu görülebilmektedir. Üst gelir grubu açısından Pareto dağılımı geçerliyken, orta ve düşük gelir gruplarında yapılan farklı çalışmalar dağılımın üstel, gamma veya log-normal olarak dağıldığını göstermektedir.

ii. Dağılımsal yapılar etkileşimdeki birimlerin geniş kümelerinden oluşan uygun modellerle açıklanabilir. Klasik mekanik temelli iktisadi açıklamalar, bütünün karakterini veya davranışlarını onu oluşturan parçacıkların toplamıyla açıklamaktadırlar (Lux, 2005: 242; Kırer, 2011: 67). Ancak Kırer'in (2011: 67) de 
belirttiği üzere bu yöntemsel indirgemeciliktir. İktisadi olarak toplumun yapısını onu oluşturan bireylerin toplamı olarak tanımlamak ve bütünsel dinamiklerin bireysel etkileşimler sonucu oluştuğunu varsaymak ancak bir bireyin davranışının başka bir bireyin davranışından etkilenmemesiyle mümkün olabilmektedir. Oysa bireyler arası etkileşim varsayıldığında bütün, tek tek bireylerin toplamından farklıdır. $\mathrm{Bu}$ nedenle birbirleriyle etkileşim içindeki iktisadi bireylerin davranışları, bütünü ifade eden toplum tarafından belirlenmektedir.

iii. Dağılımın esas kısmının (düşük veya orta gelir için) üstel veya gama dağılımına uygunluğu şans veya maksimum entropi durumları ile açıklanabilir.

Gallegati vd. (2006: 1) gelir dağılımı sürecine ilişskin olarak temelde ekonofizik modellerinin, değişim süreçlerinde enerjinin korundu istatistiksel fizik modellerine dayandığını ifade etmektedirler. İktisadi olarak enerjinin korunumu ilkesinin ilkel avc1toplayıcı toplumlarda gerçeğe uygun makul bir yaklaşım olarak ele alınabilecek olmasına rağmen; sanayileşmiş kapitalist ekonomilerde gelirin korunumundan bahsedilemeyeceğini ifade etmektedirler. Gelirin korunumu sürecinden iktisadi olarak değişim sürecinin değil, üretim sürecinin sorumlu olduğunu ve üretim yerine yalnızca değişime odaklanan modellerin tanım gereği kapitalist sanayileşmiş ekonomilerde gelir üretiminin gerçekçi bir tanımını sunamayacağını ifade etmektedirler.

Ancak gelir dağılımının analizine ilişkin ekonofizik çalışmaları yalnızca farklı ülke örneklerinin ve/veya farklı dönemlerinin istatistiksel dağılımlarının belirlenmesiyle sınırlı değildir. Cockshot vd. (2009: 140) belirttiği üzere iktisadi sorunlara ekonofizik yaklaşımlar temelde olasılıksal modellerdir. İstatistik fizik temelli bu modeller olasılıksal bakış açısıyla gelir ve servet dağılımını analiz etmektedir. Bu bağlamda Ribeiro (2020: 154-197) olasılıksal bakış açısıyla gelir ve servet dağılımını analiz eden ekonofizik modellerini sınıflandırmaktadır. Gelir ve servet dağılımının modellenmesinde kullanılan temel yaklaşımları "gelir ve servet dağılımının kinetik modelleri" ve "ekonomi politik modeller" olarak iki ana gruba ayırmaktadır. Kinetik modeller varsayımlara bağlı olarak Angle süreci (Angle Process) veya Angle eşitsizlik süreci (Angle Inequality Process -IP), paranın korunumu modelleri (The Conservation of Money), paranın korunumuna dayalı modeller (Model based on Monetary Conservation), dağılmış parçacıkların elastik çarpışması olarak değişim modelleri (Trading as Elastic Collisions of Scattering Particles), elastik çarpışma içinde vergiler (Taxes in Elastic Collisions) modellerinden oluşmaktadır. Politik ekonomi modelleri, değişim/ticaret ve yatırımların stokastik modeli olarak ifade edilebilir. Servet birikiminin ticaret ve yatırımlarla gerçekleștirilebileceğini ifade eden bu modelde yatırımlar servet yaratıcı veya yok edici işlemler olarak tanımlanırken değişim/ticaret ekonomik işlemlerin herhangi bir biçimi olarak kabul edilmektedir. Ayrıca bu modeller klasik ekonomi politik temelli değerler ile fiyatlar arasında bir ayrıma gitmektedirler. Fiyatı, herhangi bir ürüne belirli bir zamanda piyasada gerçekleştirilen ödeme olarak tanımlarken değeri, belirli bir ürünün uzun dönem üretim maliyetleriyle açıklamaktadırlar. Ekonomi politik modeller genel olarak Lotka-Volterra modellerine dayalı nümerik simülasyonlar olarak ifade edilebilir. Bunların yanında Draculescu ve Yakovenko'nun tüm popülasyonun gelirinin üstel olduğu varsayımıyla elde edilen Lorenz Eğrisini, toplumsal sinıflar arasındaki uyumsuzluğun göstergesi olarak ifade ettikleri sınıfsal yeniden dağılım (Class Re- 
distribution) modelleri söz konusudur. Çalışmanın odağını ve boyutunu aşması nedeniyle bu modeller ele alınmamıştır.

\section{Sonuç}

İktisadın temel özelliklerinden biri de diğer doğa bilimleriyle karşılıklı etkileşimin aracılığıyla zenginleşmesidir. 18. yüzyıl iktisat biliminin modern temellerinin atıldığı ve kurumsallaştığ1 yüzyıl olarak kabul edilirse, özellikle 18. ve 19. yüzyıl klasik fiziğinin iktisat üzerinde önemli etkilere sahip olduğu söylenebilir. Ayrıca klasik iktisat, neoklasik teori ve iktisadın 21. yüzyıldaki güncel teorileri fizik biliminin kavramsal ve matematiksel gelişmelerinden ve doğal fenomenleri tanımlama, tahminleme ve açıklama biçimlerinden etkilenmişlerdir. Bu etkileşimin güncel örneği “ekonofizik” yöntemidir.

Esas olarak fizikçiler tarafından geliştirilmiş olan yasa, teori ve metotları, belirsizlik, stokastik (olasılıksal) süreçler ve doğrusal olmayan/sapmalı (nonlineer) dinamiklere sahip iktisadi sorunların çözümü amacıyla kullanan disiplinler arası yeni bir araştırma alanı olan ekonofizik, iktisadın somut tahlili amacıyla, iktisadi neden ve sonuçları fiziksel neden ve sonuçlarla açıklamaya çalışır. İstatistiksel fizikten alınan olasılıksal ve istatistiksel kavramların, yöntemlerin ve modellerin niteliksel ekonomi alanına uygulanmasıyla ekonofizik temelli analizler gerçekleştirilmektedir.

Ekonofizik ve iktisat etkileşimi son dönemde gelir ve servet dağılımı konularının analizinde de uluslararası literatürde artan biçimde gözlenmektedir. Ana akım iktisatçılar gelirin, tüm bireyler arasında tam eşit dağıldığ 1 veya tam olarak eşitsiz dağıldığ iki uç durum dışında, log-normal dağılıma uyumlu olarak dağıldığını ileri sürmektedirler. Diğer taraftan log-normal dağılımın, dağılımın uç kısımlarını açıklamadaki yetersizliği çalışmaların yönünü değiştirmiştir. Bir ülkedeki gelir dağılımının tek bir dağılım biçimiyle açıklanamayacağının ortaya çıkışıyla, ekonofiziğin, iktisadi problemlere fizik yöntemlerini kullanarak çözümler araştırdığı literatürü bu noktada kesişmektedir. Uluslararası alanda farklı ülke örneklerinin içerildiği pek çok çalışma söz konusu iken Türkçe literatürde tespit edilebildiği kadarıyla yalnızca Kırer'in (2011) “Türkiye ve Almanya’nın Kişisel Gelir Dağılımına Ekonofizik Yaklaşım” başlıklı doktora çalışması bulunmaktadır.

Gerek iktisadın tarihsel gelişimi ve son dönem modern iktisat teorilerine yönelik eleştiriler göz önünde bulundurulduğunda gerekse iktisat-fizik etkileşiminin son dönem biçimi olması nedeniyle ekonofizik çalışmalarının gerçekleştirilmesi ve bu literatürün ülkeye taşınması önem arz etmektedir. Gelir ve servet dağılımının ekonofizik yöntemlerle analizi, geleneksel iktisadi analizde gözlemlenemeyen toplumsal sınıflar ve sınıf içi eşitsizliklerin incelenmesine de olanak tanımaktadır. Bu çalışma gelir ve servet dağılımı alanında bu eksikliği kapatmaya yönelik literatür sunulmuştur. Ancak niceliksel analizlerin gerçekleştirildiği daha fazla çalışmaya hem iktisat teorisinin gelişimi hem de gelir ve servet dağılımı olgusunun daha derinlemesine analizi için ihtiyaç olduğu açıktır. 


\section{Kaynaklar}

Afşar, K.E. (2013), “Menkul Kıymet Borsalarında Fiyat Dinamikleri: İMKB Örneği”, Dokuz Eylül Üniversitesi Sosyal Bilimler Enstitüsü, Yayımlanmamış Doktora Tezi, İzmir.

Akyüz, Y. (1980), Sermaye Bölüşüm Büyüme, (ikinci Bask1), Ankara Üniversitesi Siyasal Bilgiler Fakültesi Yayınları, No: 453, Ankara: Ankara Üniversitesi Basımevi.

Aoyama, H. vd. (2000), Pareto's Law for Income of Individuals and Debt of Bankrupt Companies, $<$ https://arxiv.org/abs/cond-mat/0006038>, 22.11.2018.

Arnold, C.B. (2015), Pareto Distributions, (Second Edition), Riverside CA: CRC Press Taylor \& Francis Group.

Bentes, R.S. (2010), “Econophysics: A New Discipline”, Science and Culture, 76, 1-13.

Birner, J. (2002), “A conservative approach to progress in Economics, Is There Progress in Economics?”, içinde: S. Boehm \& C. Gehrke \& H.D. Kurz \& R. Sturn (eds.), Knowledge Truth and The History of Economic Thought, Edward Elgar Publishing.

Blaug, M. (1985), Economic Theory in Retrospect, (4. Bask1), New York: Cambridge University Press.

Burda, Z. \& J. Jukiewicz \& M. Nowak (2003), “Is Econophysics a Solid Science?”, Working Paper, Institute of Physics, Jagellonian University, Krakow, arXiv:cond-mat/0301096v1, 5.11.2018.

Carbone, A. \& G. Kaniadekis \& A.M. Scarfone (2007), "Where Do We Stand On Econopysics", Physica A, 382(1), xi-xiv, Elsevier, 09.05.2018.

Chakrabarti, B.K. vd. (2013), Econophysics of Income and Wealth Distribution, UK: Cambridge University Press.

Chakraborti, A. vd. (2011), "Econophysics review: I. Empirical facts”, Quantitative Finance, 11(7), 991-1012.

Clementi, F. \& M. Gallegati (2005), "Pareto's Law of Income Distribution: Evidence for Germany, the United Kingdom, and the United States", içinde: A. Chatterjee \& S. Yarlagadda \& B. K. Chakrabarti (eds.), Econophysics of Wealth Distributon, Econophys-Kolkata I, Italy: Springer, 3-14.

Cockshott, W. Vd. (2009), Classical Econophysics, London: Routledge, Taylor \& Francis Group.

Coelho, R. (2007), Applications of Statistical Physics to Problems in Economics, Trinity College Dublin, Transfer Report, April, <https://www.maths.tcd.ie/ coelhor/Transfer_Book.pdf>, 06.02.2018.

Çakır, N. (1998), Physics and Economics, Capital Markets Board of Turkey, Publication No: 114.

Eren, E. \& H. Kırer (2017), "Eski Fizik - Eski İktisat ve Yeni Fizik - Yeni İktisat”, içinde: Ç. Boz \& K. Öğüt \& A. Deniz (eds.), İktisat ve Diğer Bilimler, İstanbul: İletişim Yayınları, 95-130.

Eren, E. (2011), "Yeni İktisatta Ortak Noktalar", içinde: E. Eren \& M. Sarfati (eds.), Íktisatta Yeni Yaklaşımlar, İstanbul: İletişim Yayınları, 13-46.

Eren, E. (2018), “İktisadi Modellemede Gelişmeler: Evrim Modellenebilir Mi?”, Efil Ekonomi Araştırmaları Dergisi, 1(1), 58-87.

Ertuğrul, A. (2014), Ekonomik Teori ve Analizin Tarihi, Ankara: Efil Yayınevi.

Fisher, I. (1925), Mathematical Investigations in the Theory of Value and Prices, New Haven: Yale University Press. 
Fujiwara, Y. (2005), "Pareto-Zipf, Gibrat's Laws, Detailed-Balance and their Breakdown”, içinde:

A. Chatterjee \& S. Yarlagadda \& B.K. Chakrabarti (eds.), Econophysics of Wealth

Distributon, Econophys-Kolkata I, Italy: Springer, 24-33.

Gallegati, M. vd. (2006), "Worrying Trends in Econophysics", Physica A: Statistical Mechanics and Its Applications, 370(1), 1-6.

Gilles, D. \& D. Sornette (2008), “Econophysics: Historical Perspectives”, The Encyclopedia of Quantitative Finance, <https://arxiv.org/ftp/arxiv/papers/0802/0802.1416.pdf>, 15.03.2020.

Goodacre, H. (2012), "Klasik Ekonomi Politik”, (çev. Ç. Dölek), içinde: F. Ben \& A.S. Filho (eds.), Marksist İktisat Klavuzu, Ankara: Dipnot Yayınları, 85-95.

Hetherington, S. (1983), “Isaac Newton's Influence on Adam Smith's Natural Laws in Economics”, Journal of the History of Ideas, 44(3), 497-505.

Hollingsworth, R. \& K. Müller (2008), "Transforming Socio-Economics With a New Epistemology”, Socio-Economic Review, 6(3), 395-426.

Jenkins, P.S. (2016), "Pareto Models, Top Incomes, and Recent Trends in UK Income Inequality", Economica, Special Issue on Inequality, 84(334), 261-289.

Jevons, W.S. (1871), The Theory of Political Economy, Palgrave Macmillian.

Kabakçıŏlu, A. (2007), İleri İstatistik Mekanik ve Karmaşıklık Çalıştayı Ders Notları, Marmaris Kuramsal ve Uygulamalı Fizik Araştırma Enstitüsü (ITAP), 01.07.2018.

Kazgan, G. (2010), İktisadi Düşünce veya Politik İktisadın Evrimi, (15. Basım), İstanbul: Remzi Kitabevi.

Kırer, H. \& E. Eren (2012), “Türkiye ve Almanya’nın Kişisel Gelir Dağılımına Ekonofizik Yaklaşım”, Marmara Üniversitesi İ.I.B. Dergisi, XXXIII(2), 19-46.

Kırer, H. (2011), “Türkiye ve Almanya'nın Kişisel Gelir Dağılımına Ekonofizik Yaklaşım”, Yıldız Teknik Üniversitesi Sosyal Bilimler Enstitüsü, Yayımlanmamış Doktora Tezi, İstanbul.

Koppl, R. (1992), "Price theory as physics: The Cartesian influence in Walras", Methodos, 4(2), 17 28.

Lux, T. (2008), "Aplications of Statistical Physics in Finance and Economics”, WP, Kiel Institute, No:145, 21.10.2018.

Mandelbrot, B. (2004), The Misbehavior of Markets, NY: Basic Books.

Mantegna, N.R. \& E.H. Stanley (2000), An Introduction to Econophysics, Correlations and Complexity in Finance, UK: Cambirdge University Press.

Marx, K. (2005), Ekonomi Politiğin Eleştirisine Katkı, Ankara: Sol Yayınları.

Menger, C. (1871), Principles of Economics, Alabama: Ludwig Von Mises Institute.

Mielants, E. (2007), “Tepki ve Direniş: Doğa Bilimleri ve Beşerî Bilimler,1789-1945”, (çev. Aysun Babacan), içinde: R.E. Lee \& I. Wallerstein (eds.), İki Kültürü Aşmak Modern Dünya Sisteminde Fen Bilimleri ile Beşerî Bilimler Ayrılığ

Mill, J.S. (1848), Principles of Political Economy, New York: D. Appleton and Company.

Mirowski, P. (1984), "Physics and the Marginalist Revolution", Cambridge Journal of Economics, 8(4), 361-379.

Mirowski, P. (1995) More Heat Than Light, Economics as Social Physics: Physics as Nature's Economics, Cambridge University Press, USA. 
Montroll, E.W. \& M.F. Shlesinger (1983), "Maximum Entropy Formalism, Fractals, Scaling Phenomena, and 1/f Noise: A Tale of Tails", Journal of Statistical Physics, 32, 209-230.

Öziş, M. (2016), “Leon Walras’ta İktisat ve Mekanik İlişkisi”, Ankara Üniversitesi SBF Dergisi, 71(4), 1241-1266.

Pereira, E.J. De A.L. \& M.F. Da Silva \& H.B.B. Pereira (2017), "Econophysics: Past and Present", Physica A, 473, 251-261.

Prigogine, I. \& I. Stengers (1998), Kaostan Düzene, İstanbul: İz Yayınc1lık.

Reed, W.J. (2003), "The Pareto Law of Income - an Explanation and an Extension", Physica A: Statistical Mechanics and its Applications, Elsevier, 319, 469-486.

Ribeiro, B.M. (2020), Income Distribution Dynamics of Economic Systems An Econophysical Approach, Cambridge, UK: Cambridge University Press.

Ricardo, D. (1817/2008), Siyasal İktisadın ve Vergilendirmenin Temel İlkeleri, İstanbul: İş Bankası Kültür Yayınları.

Richmond, P. vd. (2005), "Econophysics of Wealth Distributions: Workshop Summaries", içinde: A. Chatterjee \& S. Yarlagadda \& B.K. Chakrabarti (eds.), Econophysics of Wealth Distributon, Econophys-Kolkata I, Italy: Springer, 239-245.

Richmond, P. vd. (2006), “A Review of Empirical Studies and Models of Income Distributions in Society”, içinde: B.K. Chakrabarti \& A. Chakraborti \& A. Chatterjee (eds.) Econophysics and Sociophysics, Trends and Perspectives, Weinheim: Wiley-VCH Verlag GmbH \& Co.

Richmond, P. vd. (2006), “A Review of Empirical Studies and Models of Income Distributions in Society", içinde: B.K. Chakrabarti \& A. Chakraborti \& A. Chatterjee (eds.), Econophysics and Sociophysics, Trends and Perspectives, Weinheim: Wiley-VCH Verlag GmbH \& Co.

Rosser, J.B. (2008), Econophysics and Economic Complexity, <http://cob.jmu.edu/rosserjb>, 21.10.2018.

Schinckus, C. \& Ç. Akdere (2015), "Towards a New Way of Teaching Statistics in Economics: The Case for Econophysics", Ekonomi-tek-International Economics Journal, 4(3), 89-108.

Schinckus, C. (2010), "Is Econophysics a New Discipline? The Neopositivist Argument”, Physica A, 389, 3814-3821.

Schinckus, C. (2011), "What Can Econophysics Contribute to Financial Economics?", International Review of Economist, 58, 147-163.

Sebba, G. (1953), "The Development of the Concepts of Mechanism and Model in Physical Science and Economic Thought", The American Economic Review, 43(2), 259-268.

Shaikh, A. (2018), "Some Universal Patterns in Income Distribution: An Econophysics Approach", Working Paper 08/2018, Department of Economics The New School for Social Research, 06.12.2018.

Shulz, M. (2003), Statistical Physics and Economics, Concepts, Tolls and Applications, NY.: Springer.

Smith, A. (1776/2006), Milletlerin Zenginliği, İstanbul: İş Bankası Kültür Yayınları.

Sonüstün, B. \& S. Gül (2012), “Ekonofizik: Ekonomi ve Fizik İlişkisine Güncel Bir Bakış”, Hukuk ve İktisat Araştırmaları Dergisi, 4(1), 35-43. 
Souma, W. \& N. Makoto (2005), "Empirical Study and Model of Personal Income”, içinde: A. Chatterjee \& S. Yarlagadda \& B.K. Chakrabarti (eds.), Econophysics of Wealth Distributon, Econophys-Kolkata I, Italy: Springer, 34-42.

Stanley H.E. vd. (1996), “Anomalous Fluctuations in the Dynamics of Complex Systems: From DNA and Physiology to Econophysics", Physica A, 224, 302-321.

Stremlin, B. (2007), "Otoritenin Kuruluşu: Modern Dünyada Bilimin Yükselişi”, (çev. Aysun Babacan), içinde: R.E. Lee \& I. Wallerstein (eds.), İki Kültürü Aşmak Modern Dünya Sisteminde Fen Bilimleri ile Beşerî Bilimler Ayrılı̆̆ı, İstanbul: Metis Yayınları, 17-50.

Tong, D. (2012), Statistical Physics, University of Cambridge Part II Mathematical Tripos, <http://www.damtp.cam.ac.uk/user/tong/statphys/one.pdf>, 02.07.2018.

Ulusoy, T. (2008), "Ekonofizik ve Finans: İMKB Üzerine Görgül Bir Çalışma”, Ankara Üniversitesi Sosyal Bilimler Enstitüsü, İşletme Anabilim Dalı, Yayımlanmamış Doktora Tezi, Ankara.

Walras, L. (1965[1874]), Elements of Pure Economics or The Theory of Social Wealth, (çev. William Jaffé), London: Geprge Allen and Unwin Ltd.

Yakovenko, V.M. \& C.A. Silva (2005), "Two-class Structure of Income Distribution in the USA: Exponential Bulk and Power-law Tail”, içinde: A. Chatterjee \& S. Yarlagadda \& B.K. Chakrabarti (eds.), Econophysics of Wealth Distributon, Econophys-Kolkata I, Italy: Springer, 15-23.

Yakovenko, V.M. (2008), "Econophysics, Statistical Mechanics Approach to", $<$ https://arxiv.org/pdf/0709.3662.pdf>, 07.02.2018.

Yegorov, Y. (2007), "Econo-Physics: A Perspective of Matching Two Science", Evolutionary and Institutional Economics Review, 4(1), 143-170. 
Özyiğit, M. \& İ. Mazgit (2021), "İktisat Fizik Etkileşimi Bağlamında Ekonofizik ve Gelir Dağılımı", Sosyoekonomi, 29(48), 377-405. 